University of Louisville

ThinkIR: The University of Louisville's Institutional Repository

Electronic Theses and Dissertations

$5-2018$

\title{
Gestures of creative recovery for the egocentric actor through performance in Wertenbaker's our country's good.
}

Ross Joel Shenker

University of Louisville

Follow this and additional works at: https://ir.library.louisville.edu/etd

Part of the Acting Commons, Dramatic Literature, Criticism and Theory Commons, Fine Arts Commons, Jewish Studies Commons, Other Theatre and Performance Studies Commons, and the Performance Studies Commons

\section{Recommended Citation}

Shenker, Ross Joel, "Gestures of creative recovery for the egocentric actor through performance in Wertenbaker's our country's good." (2018). Electronic Theses and Dissertations. Paper 2996.

https://doi.org/10.18297/etd/2996

This Master's Thesis is brought to you for free and open access by ThinkIR: The University of Louisville's Institutional Repository. It has been accepted for inclusion in Electronic Theses and Dissertations by an authorized administrator of ThinkIR: The University of Louisville's Institutional Repository. This title appears here courtesy of the author, who has retained all other copyrights. For more information, please contact thinkir@louisville.edu. 
GESTURES OF CREATIVE RECOVERY FOR THE EGOCENTRIC ACTOR

THROUGH PERFORMANCE IN WERTENBAKER'S OUR COUNTRY'S GOOD

\author{
By \\ Ross Joel Shenker \\ B.A., Wesleyan University, 2011

\begin{abstract}
A Thesis
Submitted to the Faculty of the

College of Arts and Sciences at the University of Louisville

In Partial Fulfillment of the Requirements

for the Degree of
\end{abstract}

Master of Fine Arts in Theatre Arts

Department of Theatre Arts
University of Louisville
Louisville, Kentucky

May 2018 
Copyright 2018 by Ross Joel Shenker

All Rights Reserved 

GESTURES OF CREATIVE RECOVERY FOR THE EGOCENTRIC ACTOR

THROUGH PERFORMANCE IN WERTENBAKER'S OUR COUNTRY'S GOOD

By

Ross Joel Shenker

B.A., Wesleyan University, 2011

A Thesis Approved on

April 13, 2018

by the following Thesis Committee:

Dr. Janna Segal

Professor Zhanna Goldentul

Professor Paul Griner 


\section{DEDICATION}

To my parents, Yoram and Lucyna Shenker, for their unwavering support, without whom none of this would have been possible. 


\section{ACKNOWLEDGMENTS}

Thank you to Dr. Janna Segal for her unflinching honesty and brilliant editorial skills. Without her feedback, the central tenets of this Thesis could never have come to fruition. To Dr. Baron Kelly, the director of Our Country's Good and one of my first acting teachers when I was 8 years old at CTM Summer Drama School in Madison, WI. To Lois Abdelmalek, Sidney Edwards, and Mia Donata Rocchio for serving as my playmates and confidantes as we trekked along this epic three-year journey. To my Thesis Committee members: Professor Paul Griner for his insights into fusing memoir and textbook and Professor Zhanna Goldentul for her luminous realizations of costume design and general camaraderie. To my siblings, Dana Scheele and Anat Shenker-Osorio, for picking up the phone. To Samantha Joy Pearlman, my best friend and mentor, for teaching me that is through our mistakes that we grow. To the Fellowships around the world that helped me to recover. And most importantly, to a God of my own understanding, that morphs and changes every day. 


\begin{abstract}
GESTURES OF CREATIVE RECOVERY FOR THE EGOCENTRIC ACTOR THROUGH PERFORMANCE IN WERTENBAKER'S OUR COUNTRY'S GOOD

Ross Joel Shenker
\end{abstract}

April 13, 2018

This document serves as a travelogue for the creation of two roles for the $\mathrm{U}$ of $\mathrm{L}$ Fall 2017 Production of Timberlake Wertenbaker's Our Country's Good, directed by Professor of Theatre Arts Dr. Baron Kelly: namely, John Wisehammer and Reverend Johnson. At odds throughout the process were my abundant intellect and a search for vulnerability. In an attempt to find openness and receptiveness to my primary scene partner, I tried a variety of techniques including, but not limited to: Konstantin Stanislavski’s "Bits and Tasks"; Michael Chekhov's "Psychological Gesture"; Carl Jung’s theories on Archetype; F.M. Alexander's notions of "Inhibition" and "Nondoing" as expounded upon by Betsy Polatin; and Julia Cameron's “Morning Pages.” I achieved varying levels of success depending on the role and the means of application. I evaluated said success based on feedback from faculty and sensory recall of physical responses to emotion.

With a heavy focus on acting theory and technique, my original goal of achieving vulnerability on stage became consumed by the very methodologies I had hoped to employ in service of this ambition. By planning the results rather than the actions, I 
assumed the judgmental position of a director in an effort to manage and control my performance. Dissatisfied with the final product and devastated by the feedback I received from the faculty, I set out on a journey of creative recovery. Through recapitulations of works such as: Julia Cameron's Artist's Way; Eckhart Tolle's Power of Now; and the Twelve Steps laid out in the "Big Book" of Alcoholics Anonymous, I analogize the journey of recovery from alcoholism to my desired approach as a creative practitioner in the theatre. I theorize that the extreme desire for control that dominates alcoholic thinking also plagues egocentric actors. To find freedom, open-mindedness, and willingness as an actor, I have to surrender control of the process to the director, a higher power of my own understanding, and shed the need to pre-plan each performance. 
TABLE OF CONTENTS

$\begin{array}{lc} & \text { PAGE } \\ \text { DEDICATION } & \text { iii } \\ \text { ACKNOWLEDGMENTS } & \text { iv } \\ \text { ABSTRACT } & \text { v } \\ \text { EPIGRAPH } & \text { viii } \\ \text { INTRODUCTION: WHAT IT WAS LIKE } & 1 \\ \text { CHAPTER ONE: ADMITTING POWERLESSNESS } & 11 \\ \text { CHAPTER TWO: FIX, MANAGE, AND CONTROL } & 26 \\ \text { CHAPTER THREE: A SEARCHING AND FEARLESS INVENTORY } & 52 \\ \text { CHAPTER FOUR: PRACTICING PRINCIPLES } & 66 \\ \text { REFERENCES } & 81 \\ \text { CURRICULUM VITA } & \end{array}$




\section{EPIGRAPH}

Each person is like an actor who wants to run the whole show; is forever trying to arrange the lights, the ballet, the scenery and the rest of the players in his own way.

-Alcoholics Anonymous

A successful creative career is always built on successful creative failures.

—Julia Cameron, The Artist's Way

Ultimately, the only techniques that can help us are those we invent ourselves.

-Stephen Nachmanovitch, Free Play 


\section{INTRODUCTION:}

\section{WHAT IT WAS LIKE}

Each semester of the University of Louisville's Master of Fine Arts program in Performance, I was required to audition for all mainstage shows until cast. Once cast, that role served as my single credit Performance Project, and the Department Chair assigned a grade of Pass or Fail at the end of term, according to the director of the production's recommendation. However, in my fifth semester of study, I took on what is known as the requisite Thesis Performance, earning two credits and a grade on the standard A to F scale. I accepted the roles of John Wisehammer and Reverend Johnson in Our Country's Good by Timberlake Wertenbaker, under the direction of Professor of Theatre Arts, Dr. Baron Kelly.

In preparation for our semi-annual Faculty Advisory Committee meetings, the entire graduate faculty convened in private to discuss the eleven graduate students, their strengths and weaknesses, and to assign grades to the Thesis Performances executed in the Fall 2017 semester. Each Professor provided their assessment of the performance and a grade. The mean, based on U of L's standards for Grade Point Average, worked out to a $\mathrm{B}+$. My first B of any kind in the graduate program, I was devastated, filled with questions and doubts about my suitability to pursue a career in the Theatre. I pondered what kept the performance from A-level quality. Some answers came while reading over the written feedback from each professor. For example, one advisor expertly isolated the 
troublesome and sometimes mutually exclusive relationship between my intellect and emotional connection to John Wisehammer. She provided much inspiration for my Thesis in her astute observations on how my best qualities as a student became my greatest liabilities as an artist. She wrote, "[Ross] is extremely intelligent, creative, and selfreflective. These are outstanding qualities that, as he himself has stated, at times hamper his emotional connection to a role. I believe this was the case with his work on John Wisehammer...his clearly thought-out physical and vocal choices...seemed to interfere with his ability to connect with the actress playing Mary” (Semester Review, Fall 2017).

I felt as if there was a test and I failed it. From the get-go, I sought to achieve vulnerability and connectedness to the scene partner. In retrospect, where I had started in the audition room and where I ended up on opening night were two very different places. In the callback, I achieved a smudging of actor and character, behaving as myself in a relaxed state, with only the cockney dialect and nothing else placed on top. My interpretation came from the text moving through me in a liminal space somewhat akin to neutrality but more accurately described as openness. I left my choices in the lobby other than viewing that specific scene as a courtship between Mary and John. This allowed new choices to come to me, representing a breaking with habit. This session yielded much glee from the director and other faculty auditors.

Throughout the rehearsal process I began to believe less and less that I was handsome or dashing enough to win Mary's heart. I moved towards an interpretation of Wisehammer as something of a nervous clown, thereby making Mary's love for Wisehammer of the pitying or fraternal sort. In the central love triangle between 
Lieutenant Ralph Clark, Mary Brenham, and John Wisehammer, the choice for Mary became all too obvious given her lack of romantic attraction towards John. I recall one particular improvisational exercise where we asked our castmates questions while we all remained in character. Mary professed that though she loved me, she could not imagine a future where we would live together.

As I turned to my classmates and other peers for feedback, they felt my interpretation of the role was fleshed out, believable, and entertaining. Upon reflection, while I agreed my interpretation included strong choices, I questioned whether they were borne out of Wertenbaker's text or my own independent missteps. At the beginning of the rehearsal process, director Baron Kelly expressed that Wisehammer had to be a credible romantic rival for Ralph. Perhaps not wishing to interfere with my process of discovery, he seemed to let that go as we approached the performances. In pursuing such broad comic choices, I lost sight of the very thing I wanted to work on in the first place: the vulnerability inherent in romantic pursuits and fulfilling the director's original vision. When proposing marriage to Mary, I felt entirely confident she would say yes and was shocked when her gaze turned to Ralph. This made Wisehammer's portrait of a future life with Mary utterly delusional.

Conversely, the reviews for my other role of Reverend Johnson were unanimously positive. In that role's case, the droll and zany physicality, posh English dialect, and ghost white wig served as a means to send and receive energy between myself and my castmates. Due to the broader and more stock qualities inherent in the character and intrinsic to his particular scene, choices that could have been perceived as over-acting 
actually worked well in such a context. With Wisehammer's scenes, the writing possessed a stylistic quality closer to the psychological-realists of the twentieth century. In the simplest terms, the Reverend was not subtle with expressing his desires. Wisehammer possessed far more subtext and delicacy in his approach to the pursuit of his objectives. In seeking to draw starkly opposite sketches for the two diametrically opposed roles, I made the mistake of applying identical techniques in the preparation of each role. I have now come to believe that each role demands a different means of coaxing character through a careful calibration of the use of the self and outside influences. The latter reigned supreme throughout the rehearsal process, as I attempted to regulate and judge the performance from a directorial perspective. As we moved into the performance space, I existed in a constant state of harried anticipation, always thinking about the next moment instead of luxuriating in the sensualities of the present one.

As I went back through my Process Journal, I saw the many hours of hard work and preparation I poured into each role in my private practice. I found myself wondering if a better approach could have been a simpler approach. Rather than interpreting character and making choices with the director and scene partners in absentia, a focus on conditioning the instrument, relaxation, and concentration could have put me in a deeper sense of free play. Perhaps I was ready to throw away Stanislavski-based script analysis with its beat shifts and objectives, Jung's notions of character archetypes, and Chekhov's Psychological Gestures, trusting that those techniques would manifest if I only remained open enough to let them work through my enteric nerve system, my "gut-brain" rather than the one in my skull. In an effort to dispel any accusations of laziness from the 
director, I over-engaged the higher functioning areas of the frontal cortex, rather than the breath, alignment of the spine, and whole-body listening. In some perverse paranoia, I anticipate criticism from my directors that attacks my energy and work-ethic because I never think I alone am enough to credibly pull off the character from an emotional standpoint. I compensate for this through rigorous application of the intellect and in an effort to avoid the unknown. Thoughts fill my head of needing to impress the director or he will never hire me again. I begin to think my intelligence is all I have to offer, that I am incapable of being a human-being and can only be a human-doing.

While reading about practitioners at the height of their craft, such as Daniel DayLewis and Meryl Streep, I was struck by the amount of preparation they engaged in before stepping on a film set. Yet, their strong physical and vocal choices never seemed like trickery or fakery. I realized that before one can transform into a character, one must shed the default self in favor of a higher self, a neutral self, open, vulnerable, and more interested in listening than impressing the audience.

When setting pen to paper for this period of analytical reflection, I felt like some impostor. I was not an actor and never would be. How could I climb the annals of stage and screen when my performances leaned so heavily on artifice? It was then that I remembered my deeply held belief that creativity and spirituality were utterly intertwined. Perhaps there was some oppositional linkage, at times even a mutual exclusivity, between engagement of the intellect and engagement of the spirit.

In its flagship chapter "How It Works," the authors of Alcoholics Anonymous described the alcoholic as, "an actor who wants to run the whole show" (60). Throughout 
my entire career, mentors have likewise told me to stop trying to direct whatever production or project we were working on at the time. Apropos, Bill Wilson, the assumed primary author of the "Big Book," wrote that, "The main problem of the alcoholic centers in his mind, rather than in his body" (23). Using deductive reasoning (if A equals B, and $\mathrm{B}$ equals $\mathrm{C}$, then $\mathrm{A}$ equals $\mathrm{C}$ ), I concluded that the issues standing in my way of maximizing my potential for openness and vulnerability lay in my mind. I sought a protection of self, guarding against uncomfortable emotions or perceived boredom on the part of the audience by fishing for laughs and a "rational" interpretation of Wisehammer. I now understand it as a sort of, "Selfishness—-self-centeredness! That...[was] the root of [my] troubles. Driven by a hundred forms of fear, self-delusion, self-seeking, and selfpity" (Alcoholics Anonymous 62). I crafted perfectly logical and comic performances, never fully giving over to my upper-case higher Self (sic), as Jung terms it, but only my bound and protected material self. I gave the audience neurons firing on all cylinders when it came to the neck-up, but lost the sense of spirituality where skull met spine and refused to let the audience into my darker vulnerabilities. The acting techniques I studied and applied wound up fortifying my protective shield rather than breaking down the walls of intellect that prevented openness, receptiveness, and vulnerability.

The entertainment industry, "show-business," has always enjoyed a reputation amongst the public of fakery, phoniness, and self-obsession. I do not regret moving to Los Angeles immediately after college and rising in the ranks of the industry, serving as an assistant at various agencies and talent management firms. But in hindsight, I gave up my creativity in favor of $70+$ hour work weeks in the hopes of eventual fortune and 
notoriety. Still, my motives were not purely impure. I reasoned that if I couldn't be an actor myself, I wanted to help other actors realize their dreams. I didn't need to be "a creative," but could console myself as "a creative adjacent."

Once I returned to the creative work of the theater, the belief that I might live a life of wealth and glamour in New York City, solely off of my creative endeavors, lingered in the back of mind. This obsessive belief that material wealth or name recognition could bring happiness manifested as worry, anxiety, or "future tripping." I was unable to enjoy the creative project of the present because I always pondered what opportunity I had missed through my very participation. What gave me hope was a belief that the work I was doing had importance and the potential to change someone's viewpoint on the human condition. I've come to believe that to achieve this, an actor must be willing to give himself over to revealing certain facts about himself through the characters he plays. Not in a literal sense, but by experiencing those circumstances in the play that are difficult, uncomfortable, and trigger extremities of emotion in the actor.

I decided to build this Thesis as four chapters adapted from a central principle I learned from my research into the Twelve Steps and the Meetings of Alcoholics Anonymous: sharing openly and honestly. I would talk about the events of the past as I lived them, my perception of those events in retrospect, and where I might go from here. In Summer 2017, I completed week 8 of 12 in Julia Cameron's well-known Artist's Way, the week where the student finally looks over their "Morning Pages," a daily stream-ofconscious free-write. I paused and looked at her list of recommended readings in the back of the book to find a plethora of 12-step based literature. Early in the book Cameron drew 
a parallel between the journeys of recovery from alcoholism and what I think of as creative sobriety, a free-flowing stream of artistry unhampered by smarts or perfectionism.

In the Big Book of Alcoholics Anonymous, the founders insisted, "Our stories disclose in a general way what we used to be like, what happened, and what we are like now" (58). I applied the same methodology to this Thesis, albeit with much more specificity. In Chapter One, I recount my efforts to control the casting process and my eventual acceptance and excitement over the director's decision to place me in the roles of Wisehammer and Johnson. I also engage with the summer preparatory work in consultation with various historical and audio-visual resources recommended to us by the director. Chapter Two describes the weeks of rehearsal and performance, with significant excerpts of my Process Journal from that time to offer a glimpse into the chatter of my mind that overshadowed a sense of fun and free-play. This chapter also provides some methodologies for the beginning actor to try out if they are unfamiliar with Stanislavski's "Bits and Tasks" or Chekhov's "Psychological Gesture" through an innovative fusion of the two techniques. Chapter Three offers a retrospective of the Stanislavskian and Chekhovian Acting Techniques that heavily influenced my creativity. I then deconstruct and dismantle that work, explaining in retrospect what did and did not work about the methodologies employed. Finally, this chapter suggests what aspects I might retain for future work and what is perhaps best left discarded. In the fourth and final chapter, I discuss Cameron's theory of "Creative Recovery" and how actors who struggle with selfesteem can use principles contained in the Twelve Steps and other spiritual and artistic 
practices as inspiration to overcome these issues. I outline how my personal struggles as an actor in Our Country's Good and other projects run tandem to the root causes of alcoholism according to Bill Wilson and the other founders of AA. I draw parallels between the journeys that egocentric alcoholics and egocentric actors take when they embark towards recovery and sobriety, whether from alcohol or from their own intellect. I conclude that my path forward as an ego-centric actor includes a higher-power concept to help me surrender control and judgment of the performance to achieve presence.

Throughout the ensuing pages, I hope to maintain a Performative-I towards the goal of writing with openness, transparency, and vulnerability. Della Pollock describes this concept in her 2007 article for Cultural Studies and Critical Methodologies. She cautions young scholars that academic writing can lead to a potentially detached quality of voice. Perhaps by discarding any fear of the inevitable grade this thesis will receive, I can embody the self through the presentation of this research and reflection, making it simultaneously academic and artful. Pollock suggests that,

The classroom is a spatial matrix of practices that generally reiterates value hierarchies consistent with a Derridean deconstruction of speech and/or writing and classical antitheatrical biases. Here, I want to stake one view toward possibilities for performing writing in the toll paid by students who consequently continually find they are writing themselves out of themselves. (240)

Pollock seemingly offers up a hybridization or fusion of personal and academic writing. This includes writing in the first person, and even forays into creative writing that subvert 
the typical prose one sees in academic journals. In my thesis, I accomplish this through fearless and unflinching honesty when it comes to revealing aspects of my process that in retrospect now seem embarrassingly egocentric.

The same reasoning of hybridizing self with academic writing can be applied to performance in a university setting. By treating the stage as a classroom in which I was the Professor-Judge, ever tasked with ensuring the logic of my own characterizations, I lost the actor's best tool: true spontaneity. Spontaneity borne not of habitual fishing for laughs, A+'s, or other signs of admiration and praise, but of a desire to see and be seen, and to indulge in a reciprocal exchange of strong emotional attitudes between the audience, my fellow actors, and myself. I wanted to commit fully to impulses of feeling, crying, loving, and losing. However, I lost that ability by pre-planning them as held appointments rather than finding them anew each time in the present moment. I hungered to experience a parallel echo of the character's reactions. I found myself frequently falling short due to calculation and pre-meditation. In choosing relaxation and concentration towards an end of vulnerability, not out of selfishness, but in the hopes that even one audience member might identify and heal through a recognition of their own experience, I have faith that my future artist-self can transcend the trappings of the mind to achieve a creative recovery. 


\section{CHAPTER ONE:}

\section{ADMITTING POWERLESSNESS}

This initial chapter looks at the substantial portion of time leading up to the first rehearsal and my efforts to exert control over casting. I assigned much greater meaning and significance to the casting of this production since it was to contain my thesis role. Expectations abounded with the fear and anxiety that my part might be embarrassingly small. I found myself unable to accept the executive function of the director until the bitter end. Once I surrendered to the process, I discovered new capacities for vulnerability and a sense of communion with my eventual primary role. I also give a recapitulation of the summer reading and study that encompassed my dramaturgical preparation for rehearsals through assigned texts and individual research.

\section{Regarding My Audition}

I wanted to play Second Lieutenant Ralph Clark, the romantic lead. Always relegated to playing fools, villains, foolish villains, and villainous fools, I longed to attempt something I had done only on camera and never on stage. One of Our Country's Good most titillating aspects was the unique challenge of double casting. From the original production in London to its Broadway run in the early 1990s, the cast consisted of 10-12 actors, all playing two or three roles. Unfortunately, in those aforementioned and somewhat definitive incarnations, Ralph proved an exception. Thus, to play Ralph probably meant losing out on the challenge of a doubling track. After playing tracks with 
multiple roles in professional productions, this opportunity to delve into such a challenge with the weight and depth that a graduate thesis role might command felt like too great an opportunity to pass by. Nonetheless, and perhaps in no small part due to ego, the lead role left me salivating in some Pavlovian response, enticed by the idea that I might carry the entire show on my soldiers, single-handedly in control of its success or failure.

It was April of 2017, over six months before opening night, but the director, Dr. Baron Kelly, wanted to see certain actors read before leaving for the summer. If I could determine the thesis role before departing, the summer could serve as ample opportunity to memorize the lines and lend more specificity to my preparation. I began to set up a dynamic where my collaboration and involvement was contingent upon certain expectations being met; the efforts to control the entire thesis process had begun.

After reading for just about every male role in the script one-on-one with Dr. Kelly, I continued to push for consideration as Ralph. I asked an undergraduate if she would read "A Love Scene" with me for my director and my thesis advisor, a steamy romance scene between Ralph and Mary set on the shores of a moonlit beach. We got together and rehearsed, were both off book, and I choreographed our kiss and movements. Though I knew it inappropriate to direct a fellow actor in the context of an audition, I thought that this possibly being my thesis role gave me license to manipulate and orchestrate the callback process. Rather than letting go and surrendering to the fundamental concept of auditioning, I tightened my grip thinking I could be both casting director, actor, and even stage director simultaneously. Anyone who has sat or stood on either side of the table knows these positions are almost always mutually exclusive. 
Ironically, had I just let go, Dr. Kelly likely would have told me I was to play John Wisehammer and Reverend Johnson and my desire to know the roles before summer break would have been fulfilled.

In a generous showing of collaboration, Dr. Kelly decided that I should study the play in a more general sense over the summer and keep an open mind as to the possibilities in casting. I analyzed and speculated on how I might be cast, resentful at suggestions from faculty that a Wisehammer/Reverend track was in the cards. I resisted the notion, drawing out charts comparing the stage time of each character, grimacing at the thought that an undergraduate might play a role larger than mine. Traditionally, Wisehammer is doubled with Captain Phillip. With that scenario at least my stage time would be nearly comparable to the actor playing Ralph.

The idea that third-year graduate students had a great deal of control over the determination of their thesis role proved false time and time again during my tenure within the Department. However, in my second year I observed three out of four thirdyears play lead roles and one tackle Edmund in King Lear. I thought these assignments superior to my own and failed to heed my own mantra of, "compare and despair." Thus, a certain amount of trust and admission of powerlessness in the process could have alleviated some stress. In Twelve-Step work, this mirrored the admission of powerlessness found in Step One: "We admitted we were powerless over alcohol" (Alcoholics Anonymous 59). It also reverberated with Step Three: "Hereafter in this drama of life, God was going to be our director" (62), though in this case I could analogize the reading more literally and let Dr. Kelly be the director. Alas, I could not 
muster the willingness for such sentiment. My desire for control over the production had already begun, and we were still months away from the read through.

Over the summer, I completed notations and annotations on certain fundamental texts assigned to us by the director as a means of background information towards inspiration. First, I read The Playmaker by Thomas Keneally, the novel upon which Wertenbaker adapted her play. Second, I enjoyed the first hundred pages of The Fatal Shore, Robert Hughes's non-fiction tome on the founding of Australia. Third, I engaged relevant passages in Mayhew's London Labour and the London Poor. One chapter, entitled "On the lives of street-Jews," gave a comprehensive account of what life was like for the 18,000 Jews living in London during the late 18th century. Finally, I looked at sketches and paintings by William Hogarth, the 18th century cartoonist who drew vivid depictions of prisons, lunatic asylums, and street scenes of the lower class.

The Playmaker turned my attention toward Harry Brewer, the alcoholic Midshipman and confidante of Ralph. They were the main characters, again feeding my expectations to play a large role and have ample source material to fuel my creation of character backstory. This also reflected my desire for an intellectual rather than imaginative approach to creating a role. The Mayhew chapter did excite my curiosity as far as what role Wisehammer's Jewishness played in his experiences both in London and Australia. However, his minimal page time in the novel was always filtered through Ralph's perspective, and I continued to think the role beneath me. Hogarth's work provided fuel for the imagination in a way the texts could not. Whereas language put very 
specific images in my head conjured by the author, Hogarth's work taught me to imagine the lives of his subjects separate from the characters in Wertenbaker's play. The sights, sounds, and smells were entirely my own associations and in a way a less cerebral sort of preparation.

I supplemented Dr. Kelly's assignments with personal interests, such as Julia Cameron's Artist's Way and Michael Chekhov's On The Technique of Acting. While directing for summer stock in Illinois, I used these works to engage my imagination with creative writing exercises, like Cameron's "Morning Pages," a stream-of-consciousness, three-page, free-write meant to unblock and create a conduit for the creative spirit to come out. It proved a nice respite from the sometimes dense and old timey language in Hughes's and Mayhew's tomes.

Upon returning to campus for the fall, I surveyed the manner in which previous directors chose to track the doubling. It became apparent that my existing theatrical resumé might lead me down the very path I sought to avoid: playing Major Ross (the villain) doubled with Ketch Freeman (the innocent fool). Though I felt I could pull off Ross and Ketch with ease and aplomb, such casting was not in line with the goal of a thesis role as I had heard it described in faculty meetings - namely, stretching the student beyond their own perceived capabilities. To strike a balance between my existing strengths and what might push and challenge me, it became clear that John Wisehammer, the literate, sensitive, and Jewish convict of the bunch, might accomplish such a task. Reverend Johnson, the puritanical clergyman tasked with saving the convict's souls, could provide opposition in the form of gravitas, quietude, and age. Given my personal 
research interests in Jewish and Religion Studies, and my Ashkenazi ethnicity, the two roles offered representations of both aspects of Judeo-Christian culture and thinking. Though both Dr. Kelly and my Thesis Advisor, Dr. Janna Segal, hinted as much months prior, I stubbornly clung to other options so I might take a bow at the end, rather than the middle, of the curtain call.

With egoism still in play, Second Lieutenant Ralph Clark continued to draw me, yet such casting wasn't in line with the director's vision. He felt placing me in such a role would not serve the story. "You're not a leading man or an ingenue," he said during one phone call, "you're a character actor with a particular range of strengths and skills" (Shenker 24). Dr. Segal also pointed out that Ralph's motivations were largely his desire for promotion and pelvic struggles due to a puritanical upbringing in conflict with an unquenchable libido. Though my initial intention to utilize romance as a means of vulnerability proved spot on, Wisehammer showed himself to be more centered in the chest than the pelvis. This idea of imaginary centers, primarily in the head, chest, or pelvis - corresponding to thinking, feeling, or willing qualities — proved a central tenet of my engagement in the Michael Chekhov technique throughout the rehearsal process. The quality of "feeling" Wisehammer required, centered in the heart and sternum, scared me. In my real and daily life, I led with the head and pelvis forward, leaving that heart center behind. Wisehammer's eventual rejection by Mary Brenham provided a moment of heartbreak devoid in Ralph's tracking. What I thought of as a negotiation proved to be an exercise in letting go and trusting that the faculty had both the production and my best interests at heart. I had to surrender to win. 
Looking back over my notes from late August, as "Audition Week" progressed I eventually stopped fighting for control over casting and leaned into the roles the faculty had been hinting at since April. The first night, I prepared "Harry Brewer Sees the Dead." I brought in a prop bottle of alcohol, sat in a chair, and restrained my arms behind my back. According to my journal,

I worked hard at crafting distinct voices for the ghosts and Harry himself. I tried to make big vocal choices with large variations in dialects and pitches. The director said it was too studied, too intellectualized, too thought out. He came up behind me and restrained me, giving me something physical to work against. It really activated me. I prepared and prepared and in the end it was his adjustment and direction that led to spontaneity and freedom. I devolved into a shame spiral, wondering, "Why hadn't I come up with those choices?" I had done so much research, but the solution was so simple in having something physical to work against. (46)

My primary mistake lay in once again staging the scene myself, this time with the addition of props and furniture. I came in with such a fleshed-out take on the scene it left little room for the director's interpretation.

For the following two nights of auditions and callbacks, I resolved to let my preparation go and remain open enough to immediate stimulus in the room. Again in my journal I also charted this progress: 
At first I was drawn to Ralph and Harry, but I'm shifting to excitement about Wisehammer and accepting the feedback of where I fit best at this time. I moved away from a habit of working and discovered how my process can move into another level of creativity. This resulted from absorbing and listening to the scene partners and auditors. I let go of trying to control the casting process. (47)

I remember thinking of the role as just me plus the cockney dialect. With no preconceived notion of character, the pressure to perform or demonstrate some virtuosic and technical prowess vanished. I felt dropped in, relaxed, and in a place of nondoing. By inhibiting my habitual approach to auditioning, where I pre-planned and controlled the process as a means to meet expectations, I found freedom. Just before entering the theatre for that callback, I remember thinking about discovery of the text at the moment of speech. Rather than placing anything onto the text I remember feeling genuinely curious about what the words themselves might invoke by way of intention and inflection.

Once, while auditioning for the Las Vegas premiere of Rock of Ages, every singer, myself included, decked themselves in full 80s hair and costume. My friend showed up in flats and a simple black dress. She was herself and booked the lead role. As I looked at the cast list for Our Country's Good, a potential Thesis title occurred to me: "Get Over Yourself: A Practical Guidebook For The Ego-Centric Actor” (48). Finally, I got out of my own way and accepted the roles of Wisehammer and Reverend Johnson. 


\section{Preparations for Production at my Desk}

Pre-production began in earnest and I had one month to go before the table read. I returned to the source texts assigned for summer reading. I found maximum benefit from The Playmaker and The Fatal Shore due to their descriptions of the environment, both on the ship and in the camp itself. Both works suggested that Australia was something of a foreign planet to the new settlers, particularly, as Hughes explained, due to the foliage:

Until the late eighteenth century no European had ever seen a eucalypt, and very strange they must have looked, with their strings of hanging, half-shed bark, their smooth wrinkling joints (like armpits, elbows or crotches), their fluent gesticulations and haze of perennial foliage. Not evergreens, but evergrays: the soft, spatially deceitful background color of the Australian bush, monotonous-looking at first sigh but rippling with nuance to the acclimatized eye. (3)

Keneally echoed these observations in his novel. The protagonist saw, “...Obdurate eucalyptus trees of a type which (as Ralph was assured by scholars like [Judge Collins]) occurred nowhere else in all Creation" (35). These descriptions unsettled me. I longed to travel to Australia myself, as if my imagination might not be enough to conjure up the environment. Then I remembered the wilderness of Sonoma, California while camping with my sister and nephew. We drove up from Oakland and that stark of contrast of urban and rural gave me insight into how jarring Botany Bay must have been for the previously London-dwelling colonists. The bodily personifications of the trees and the color palette 
kept bringing me back to the deserts of California and convinced me that perhaps modern-day Sydney and San Diego were not that far off from one another.

Keneally's novel also established a dichotomous environment with two clear camps within the larger settlement, divided by a natural stream, which proved useful to the imagination once I took to the rehearsal hall. The author proposed that, "Once you were across the stream, you were on the better...side of things... Those convicts who had trades and a good record lived here. So did many public officials" (37). For Wisehammer, I imagined his station changing throughout the play. While courting Mary towards the end of Act One, thinking of myself on "the right side of the tracks" provided an extra layer of discomfort to heighten the nervous energy while interacting with the object of my affection. I imagined Wisehammer as a builder unaccustomed to such labor, furthering my anxiety and need to prove my competence to Mary.

The realities of the lead-up and experience of seafaring to Australia provided ample details to feed my mind's eye. Due to the end of the Revolutionary war, England had one less locale where it could send its prisoners, and local jails such as Newgate began to overflow. Hughes wrote of the King's question, "Clearly, transportation must begin again — but to where?" (42). He went on noting that the convicts sat aboard the unmanned and dilapidated vessels for months: "The Thames and the southern naval ports of England were dotted with hulks—old trop transports and men-o'-war, their masts and rigging gone, rotting at anchor, but still afloat and theoretically habitable. Convicts sentenced to be transported would now be kept on them until the government decided where to send them" (41-2). When they finally did embark, "Four transportees [sic] lying 
in a space seven feet by six feet, the dimensions of a modern king-size bed, were the norm" (69). Taking over two years, with stops in Rio De Janeiro and Cape Town, the convicts were not allowed to leave the ships during these ports of call.

Descriptions of the ship in Hughes's book were shocking and lent a visceral sense, particularly of smell, to the opening scene of the play. I felt physically ill and grimaced when reading passages like this:

The bilges were foul in all of the ships. Even those whose guts have heaved at the whiff from the boat's head at sea can have little idea of the anguish of eighteenth-century bilge stink: a fermenting, sloshing broth of sea water mixed with urine, puke, dung, rotting food, dead rats and the hundred other attars of the Great Age of Sail. (79)

I had no frame of reference for this particular cocktail of smells. Thus, in Wisehammer's opening speech, trying to grapple with these circumstances on a purely intellectual level seemed impossible. With Dr. Kelly's help, I employed certain theories of Atmosphere, coined by Michael Chekhov, which I'll discuss later. I set these passages down in my journal. With their initial purpose - feeding the subconscious - completed, I could return to them for inspirational reminders while beginning to rehearse.

I also turned to a 2005 television series entitled The Incredible Journey of Mary Bryant, to concretize images of the ship and shore. Shot on location in rural Australia, the BBC did me the favor of bringing Hughes and Keneally's prose to verisimilitudinous life. The prose made me imagine certain plants and colors but still in the context of our playing space, like an augmented reality. The television series had me imagining myself 
in Mary's place, in a fully fleshed out virtual reality, transporting me to the other side of the world through the modern innovation of cinema. By completing much of this research before the rehearsal process began, I sincerely hoped it would not consume my main focus of growth as an actor once in the rehearsal hall: developing a strong and sensitive body that could listen to my primary scene partner.

I wondered where to begin to trace and sketch these two distinct characters, and in that very statement I found my answer: they were two distinct men—and a priori was drawing distinctions. Wisehammer asked, "What? Play two parts? It'll confuse the audience...What if they aren't paying attention?" (Wertenbaker 88). Immediately I noticed that they fell on opposite ends of a class-based spectrum. This guided my initial line of inquiry. At the top was Reverend Richard "Dick" Johnson, the Christian Minister tasked with building and maintaining a church in the new dwelling of his parishioners, despite having no edifice with which to do so. On the other hand, John Wisehammer was a London street-Jew sentenced to seven years because he, "Grabbed a packet of snuff from an apothecary's counter" (Hughes 72). Early on in the process, the director encouraged me to find clear distinctions between the two men in their physical and vocal qualities. I believed firmly that if the craft of the actor proved sound, any potential audience member could observe rehearsal and understand when the doubling took effect. Thus, I built the two men with widely different gaits, gestures, pitch variations, and psychological objectives.

Even though Johnson and Wisehammer differed in their use of Received Pronunciation (standard British) for the former and Cockney for the latter, this sketching 
of visual and aural distinctions had to go beyond the dialect work. The dialects were created largely in private work on my own and with the dialect coach, Professor Rachel Carter. The director rarely gave notes specifically about this highly technical aspect of my performance. It reminded me of the role that costumes, hair, and make-up play in the creation of character. These technical elements were prepared separately from the rehearsal hall and then fused together or put on top of what the cast and director crafted with four walls, a hard wood floor, fluorescent lighting, and some wooden boxes.

While journaling about the roles, two opposing shapes came to mind: a line and a curve. I started sketching in a notebook, much like Anthony Sher in his Year of the King. Because of his high status and non-labor based profession, I tried a stiff and upright posture for Johnson. Meanwhile, in his first dialogue-driven scene, Wertenbaker gave Wisehammer the action of, "Carrying bricks and piling them to one side" (49). His gentle and protective treatment of Mary, along with this initial stage business, made me think of his movements as more rounded and softer than the Reverend. This manifested as a hunched posture with a fetal curvature of the spine for the convict, and a secondary extension for the clergyman with the chest puffed outwards.

Though these approaches to carrying the bricks versus lecturing on the importance of marriage drew a stark contrast between the gentle sloping movements of Wisehammer and the sharp, staccato extensions of the Reverend, I had trouble finding ease in such positions. As Wisehammer, I contracted my solar-plexus and diaphragm, leading to a self-protective stance that cut off some of the vulnerability I found in the callback. Still weeks away from joining the ensemble, already I was making decisions, 
not choices. The former implied something concrete and implacable, the latter a type of preparation that might allow for input and influence from other collaborators. In my initial one-on-one with the director, he again reminded me, "Be careful of not being too studied" (61). Unbeknownst to him, that ship had already sailed. Unbeknownst to me, it led to a modality of pre-planning performance, of perhaps making choices forcefully, rather than letting them come naturally through the methods of absorption and full-body listening I had found so deeply in my last callback as Wisehammer. 


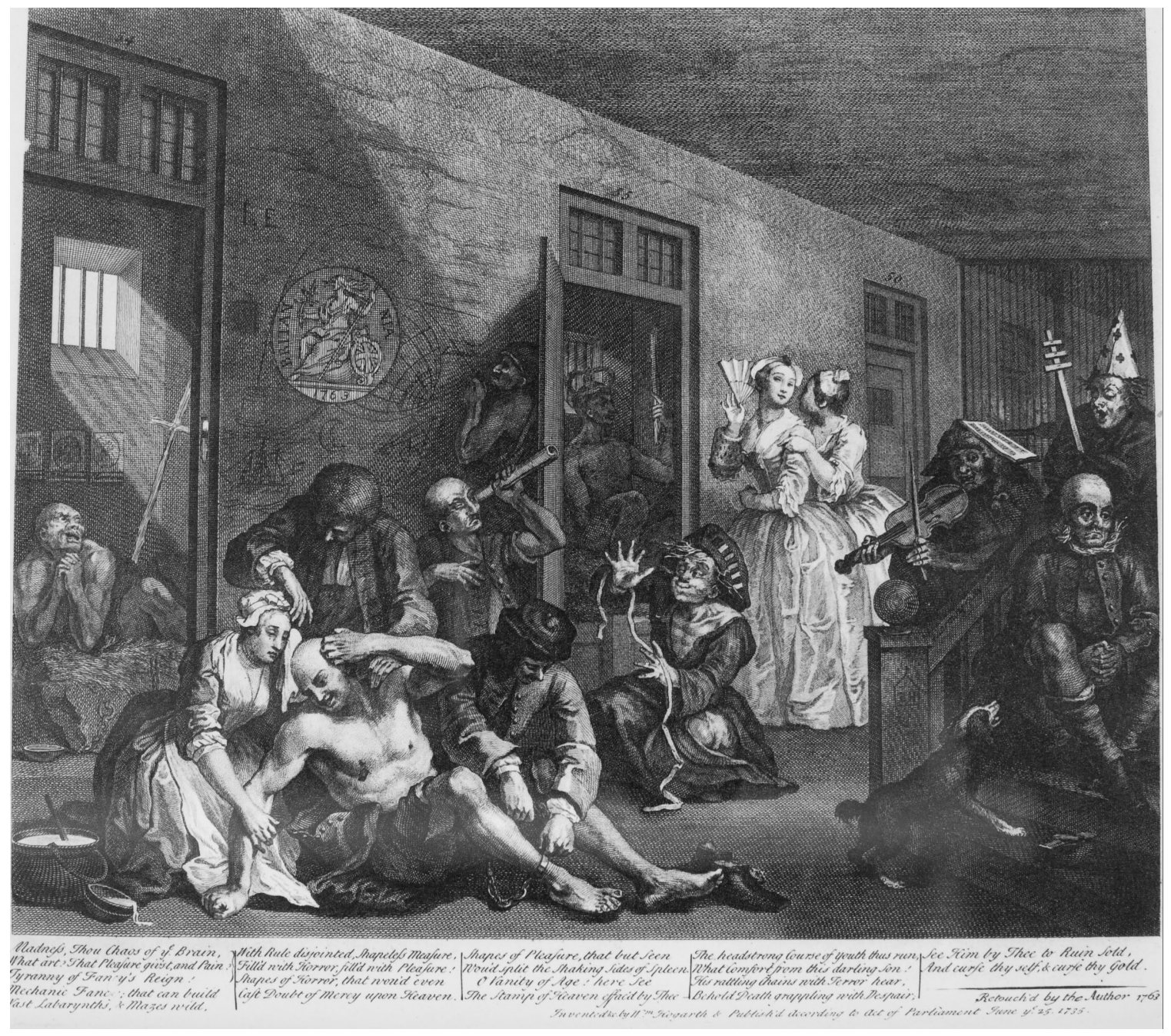

Figure 1. William Hogarth's final plate of $A$ Rake's Progess, a collection of 8 paintings telling the story of one gentleman's descent through vice and madness. The playfulness in the image fired my imagination as I read and re-read Our Country's Good over the summer. 


\section{CHAPTER TWO:}

\section{FIX, MANAGE, AND CONTROL}

This chapter recounts the rehearsals and performances from the day the actors assembled as a cast for the first time to when we took our last bow before a live audience. I describe the considerable preparatory work I put in before each staging and working rehearsal and my innovative approach to fusing Konstantin Stanislavski's "Bits and Tasks” with Michael Chekhov's “Psychological Gesture.” As I argue in Chapter Three, for the beginning actor who feels they work more from instinct than technique, I believe this approach can provide a useful case study. The intermediate or advanced actor wellversed in techniques originated at the Moscow Art Theatre can witness what happens when such technical preparation can become an addiction that subsumes spontaneity in the rehearsal room and on stage.

\section{Setting the Stage}

Before the first read-through, the cast enjoyed design presentations from Professor Kevin Gawley, Assistant Professor of Scenic and Lighting Design, and Zhanna Goldentul, Assistant Professor and Resident Costume Designer. Dr. Kelly began with a clip from Steve McQueen's 12 Years A Slave. The scene depicted Solomon Northrup, played by Chiwetel Ejiofor, as he savagely whipped his fellow slave Patsey, played by Lupita N'yongo, on the orders of their master. The director expressed his desire to depict the violent and vicious treatment of the convicts by their Red-coated captors in this 
manner. He noted the irony that while the audience might not flinch at the beating of Sideway in the opening moments of the play, they would squirm at the sexual and profane language of Wisehammer's ensuing salvo of a monologue.

Dr. Kelly posited that the play could have profound resonance with our present moment in history. The play was to open a mere two days after the one year anniversary of the 2016 election of Donald Trump. I imagined those red hats bearing the insignia, “Make America Great Again,” and considered the director's two initial questions. First, "What does it mean for a country to be our country?" Second, "What does it mean for a country to be 'good?'” In an effort to divert my attention from such cerebral matters, I decided I would not take on the responsibility of communicating these themes. I took the notes in to be sure, but let go of any deliberate attempts to communicate overarching philosophical themes to the audience. I believed such things to fall under the purview of the director, whereas I tried to focus on my role in the process solely as an actor. In hindsight however, I think answering these questions as the characters could have proved a useful thought experiment in setting up their emotional attitudes towards the power structures at play in their new home of Botany Bay. As the Reverend, I might say Christian oversight of all government and proceedings would lead to a country in line with Christ. As Wisehammer, an agnostic democracy that provides equal opportunity for all people to thrive seems more intrinsic to the notion of a good country.

Dr. Kelly also noted that while the play had modern resonances, the setting was a world apart from our own in terms of time and place. He spoke of the need for us to transform and, "Go beyond our default selves." He spoke of these chracters as, "An 
unwashed people," whose realities were so far removed from our own we would need to shed our modern skins. My interpretation of that direction wound up placing me a bit askew in terms of relaxation and vulnerability, leading to a sort of artifice or mask for both characters. I thought I had to develop a stance and voice completely opposite from my own. Such an approach led to holding and stiffness rather than the fluidity to listen and respond to a scene partner. This problem of statuesque immovability compounded due to my focus on archetypes as a guiding touchstone throughout the duration of the rehearsal process.

For Reverend Johnson, my approach led to a broad comic performance that served as satire and actually grounded me in my relationship to the other actors on stage. Seated on a rock for the entire scene, I felt solid, focused, and radiating energy towards each actor on stage. Many faculty remarked that they couldn't recognize me for the first few moments of the Reverend's scene, high praise in my opinion. His old age and cameosized role allowed for a commedia dell'arte interpretation of Kelly's direction to, "Go beyond the default self." My primary mistake lay in using an identical technique to develop Wisehammer.

As I listened to Professor Goldentul and considered her sketches, I learned that the Reverend's costume consisted of a hat, wig, glasses, and significantly more clothing than Wisehammer. Closer to my age and dressed with far less accoutrement, Wisehammer did not leave me anything to hide behind. I needed to reframe my understanding of Dr. Kelly's instructions, but alas this discovery was made in hindsight. In a later chapter, I utilize Betsey Polatin's approach to the Alexander Technique to redefine "Going beyond 
the default self" as becoming reintroduced to parts of yourself that were lost to habitual use of the self (30). In The Actor's Secret, she posits that, "We are not trying to get rid of anything. We are trying to have more options as a choice of response" (19). It turned out that my habit for broad comic choices worked just fine for the Reverend, but Wisehammer's story arc required discovering choices buried inside my self, yearning to be freed. Albeit an extremely reductionist view, some theatre scholars who write for the layperson, such as Thomas Hischak in his Theatre As Human Action, refer to this as the “Outside-In vs. Inside-Out” approach. I primarily employed the former for both roles, rather than using alchemy to mix the two or assigning the former to the Reverend and the latter to Wisehammer.

Dr. Kelly then offered up some nuggets of dramaturgy to give us a sense of the atmosphere of the world of the play. He spoke of tremendous injustice and inequality when it came to the poor. He spoke of the episode so vividly described in Hughes's Fatal Shore in which Newgate Prison was so crowded that the ships on the River Thames acted as a holding pen for the convicts. He discussed how children would have been privy to hangings from a young age, that the poor lived a sub-human, animal sort of existence.

The presence of feces, urine, vomit, and the crusty remains of salt water made the voyage to Australia a sort of living hell. Then, upon arrival to Botany Bay, starvation was a real and ever present threat. I found these remarks such tremendous fuel by way of understanding the horrendous circumstances of these characters lives. I returned to my notes from that first day frequently, trying to imagine what years without proper hygiene, dental care, or really health care of any kind meant for these poor souls. 
Finally, Professor Gawley used many visual aides to give us a glimpse into our playground: the set we inhabited six weeks later. He promulgated the nautical theme that came to influence the color scheme and materials employed in constructing the scenery. In production meetings, the staff pondered what might have happened if the convicts and officers had to make use of the ship in constructing their lodgings? Tents constructed from sails, the Captain's quarters, rocks, sand, ropes, and wooden planks made up a brown, gray, and beige color scheme reminiscent of Master and Commander or MobyDick. In a particularly ingenious touch, the curtain for the play within the play was a sail rigged to come up and down a mast. These touches reinforced the notion that the action of the play all sprang from the opening scene set aboard the ship itself. The stark dichotomy between the Captain's quarters and the rest of the set constantly reminded me of my lower status as Wisehammer, and my superior position as the Reverend. The color scheme reinforced my awareness of the poverty and desperation ever present in the colonist's lives.

\section{Table Reading the Competition}

As we launched into our first table read, I found myself in a state of comparison. On my very first line, I ended with a downward inflection. The director asked me to pause and inquired about the punctuation. There was a question mark. I felt foolish, like a novice, for ignoring the clear demarcation for an upward inflection at the end of the sentence. From there on out, the night became a matter of ego, comparing myself to the 


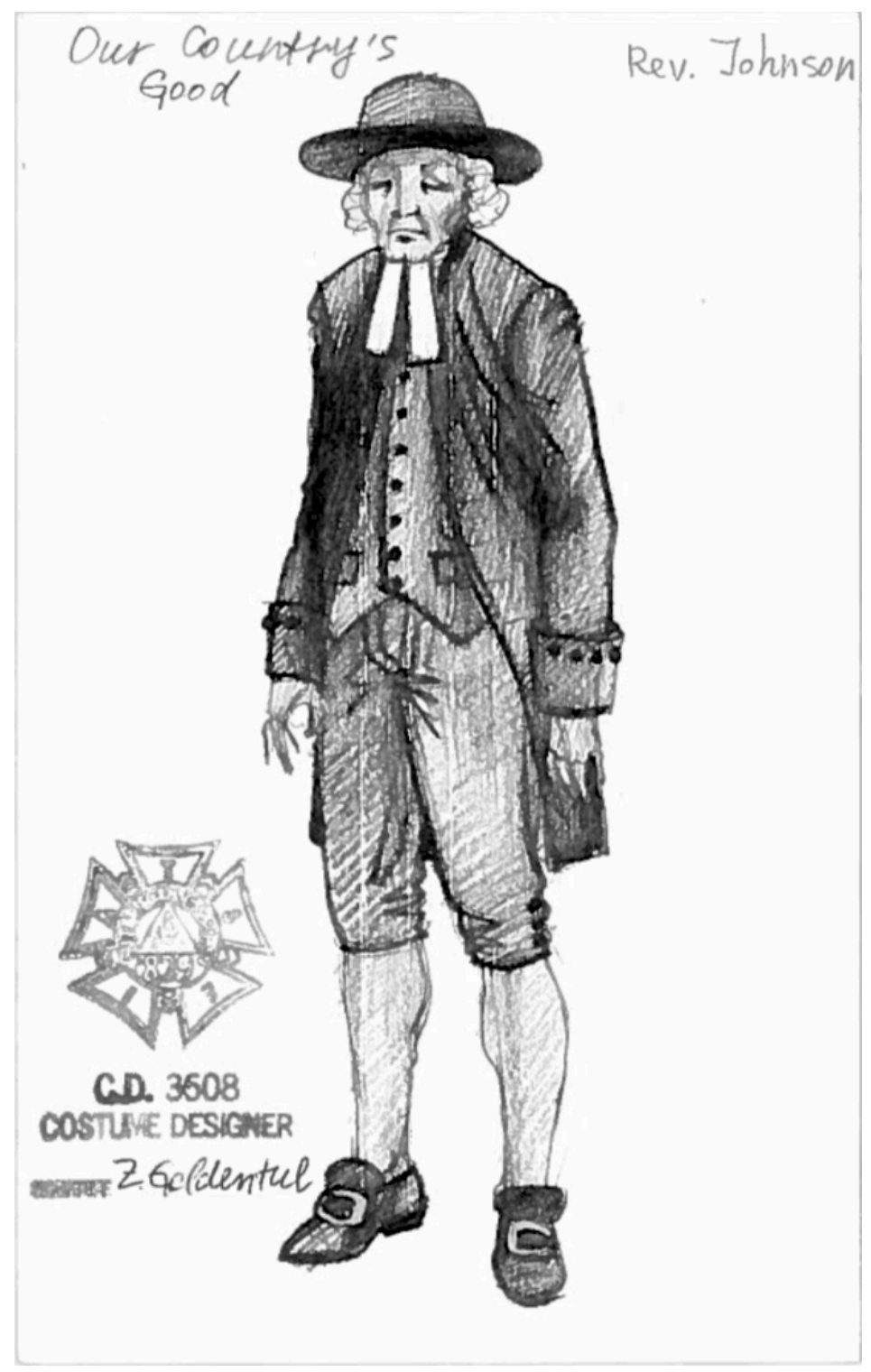

Figure 2. Professor Zhanna Goldentul's sketch for the costume design of Reverend Johnson. The spindly fingers synchronized with my linear and staccato thoughts for his movements. 


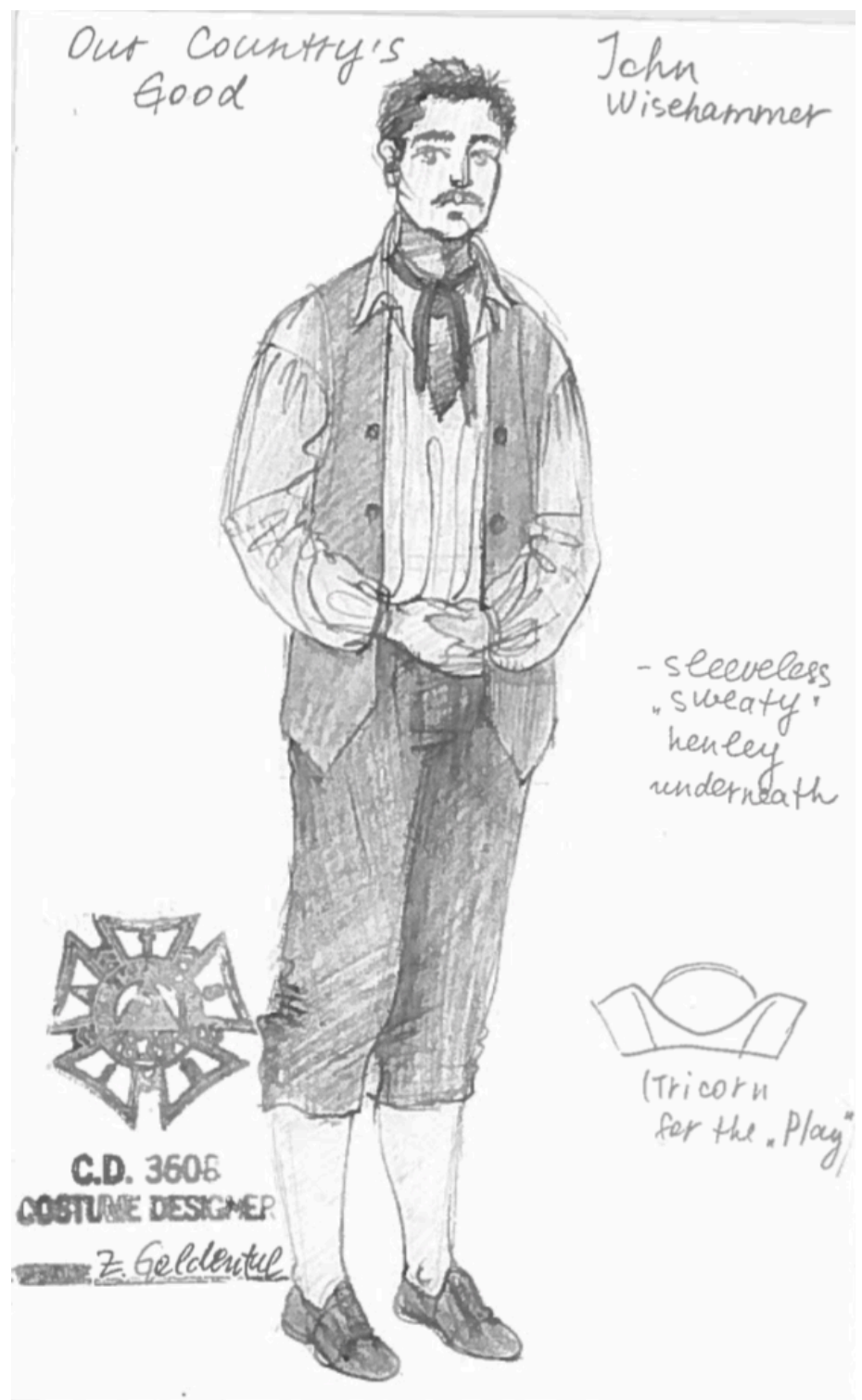

Figure 3. Professor Zhanna Goldentul's sketch for the costume design of John Wisehammer. His folded and rounded hands also synced with my idea of him as gentle and with rounded and legato qualities to his movements. 
rest of the cast and even professionals in the acting field at large. I felt a sense of superiority when it came to accuracy and authenticity of dialect. I could not relax and felt an apprehension about the whole thing. I wanted to look over at the actress playing Mary Brenham, but was too scared to actually do so. The notion of eye contact, seeing and really being seen, proved an insurmountable task, at least at that point in the process.

I was already hung up on certain preparations and decisions I had made before entering into our first read-through. I chose a goal for Wisehammer, the overarching super-objective of surpassing Ralph Clark. After taking Mary in, this initial choice fell by the wayside as I realized Ralph Clark was actually an obstacle standing in my way towards finding companionship. The warm and inviting presence of the actress playing Mary made me put my focus wholly back on her, reminding me of the lovely chemistry we found when reading together in a callback session. Some of the resentment over losing out on the lead role had wormed its way into my prep-work. I wanted to out-do my colleagues and prove my craft as an actor, as if the whole production were some sort of competition. My line deliveries were pre-planned rather than springing out of stimulus from the ensemble. I constrained my larynx to push and project the sound out, overacting and overcompensating for feelings of inadequacy. I was stuck in my head from all the decisions I had made at a desk on my own well before the first rehearsal had ever begun. Script Analysis on its Feet: Fusing "Bits and Tasks" with "Psychological Gesture"

A devoted reader of Stanislavski, his writings on script analysis and creating a score for the character proved something of a religious text for me. Since college, high 
school even, I learned of his influence on practically every American teacher or practitioner of stage acting. Armed with incisive new translations by Jean Benedetti, I vowed to renew my commitment to his teachings and endow every scene with bit or beat shifts, tasks expressed as verbs, obstacles, and creative titles for each unit of action. Take Act One, Scene Six for example, Reverend Johnson's only scene in the play. I turned to An Actor's Work On A Role - prior translations typically titled this work Creating A Role —and went over Stanislavski's written score for Othello.

\section{Bit A (I)}

Ha! Ha! False to me?

Task: need to decide why or for what reason Desdemona has been false to me. So the task and the bit is called Why? (36)

This is the closest example I could find to a template for scoring a scene. Its methodical and scientific means for breaking down a scene appealed to me. I could walk into rehearsal confident that if asked to show my work, I had a mathematical proof to indicate as much. In An Actor's Work, Stanislavski spoke of the importance of dividing scenes into "Bits" and "Tasks." By breaking a play into scenes and then into units of action, the actor could create a written score like a musician reading music. He insisted that, "There is a creative Task stored in each Bit. The Task arises organically out of its own Bit, or, vice versa, gives birth to it" (140). This relationship between subdivision and identification of an intentional action put the character's deepest desires and the tactics employed to achieve those desires at the forefront of the actor's mind. He also counseled, "never to define a Task by a noun. Reserve that for a Bit, a Task must invariably be defined by a 
verb" (148). A verb could be played as a physical action, so the bit could become about doing something specific in order to achieve a goal. A side note: bit and beat are used interchangeably, likely due to the mispronunciation of the word "bit" in a Russian accent.

I followed Stanislavski's guidelines while also using elements of the Atlantic Theater Group's Practical Handbook, the flagship text for David Mamet and William H. Macy's technique known as "Practical Aesthetics," and Robert Cohen's idea of "GOTE," an acronym for Goal, Obstacle, Tactic, and Expectation. Each provided worksheets that engendered a feeling of preparedness and eased performance anxiety. I could not be perceived as lazy because I had a notebook full of evidence to the contrary. This fear was borne out of a competitive streak; if I couldn't be the best actor, at least I would be the smartest and most prepared. These methodologies had also served me in production after production with directors who mostly left me alone to my process, leading me to believe they liked my work. Due to a desire to please others and prove my stage-worthiness, the thoroughness and honesty of my journal revealed that these twentieth-century practices were not the be-all-end-all of acting technique like I thought.

The following example of script scoring breaks down Act One Scene Six, which Wertenbaker titled "The Authorities Discuss the Merits of the Theatre." Lieutenant Ralph Clark presents his case to Captain Phillip and the other officers as to why they should produce The Recruiting Officer with a cast of convicts. While working alone, I chose to start with a written score for the Reverend because with only one scene, his arc was the simplest. 
Goal or super-objective: I want to ensure the play is within Church doctrine and beneficial to the colony at large

\section{Bit A}

Title: Balance and Order

Tactic, beat objective, or task: to mediate the discussion

Obstacles: Major Ross's foul language and unbalanced nature

Expectation: order and civility will be restored to the conversation

\section{Bit B}

Title: Morality Play

Task: scold the officers, shift blame off of the women, and bristle at the mention of my wife

Obstacle: the women are being blamed for the immorality of the officers Expectation: a lessening of the rampant whoredom

\section{Bit C}

Title: Reformation

Task: consider and measure the potential impact of the play's

production

Obstacles: I'm uncertain as to what the scripture has to say on the matter of plays

Expectation: I will gather more information on the particulars of Ralph's play and others will value my viewpoint, especially Captain Phillip 


\section{Bit D}

Title: The Negations

Task: to confirm the play does not propagate Catholic doctrine

Obstacle: Farquhar, the author of The Recruiting Officer, is Irish and his work may negatively influence the colony

Expectation: Ralph will assure me of the play's wholesome nature

\section{Bit E}

Title: Entertaining The Notion

Task: to support Ralph

Obstacles: Ross and Tench argue against him, Dawes is utterly distracted Expectation: Collins, Phillip, Ralph, et. al. will win the argument

Bit F

Title: Ralph Speaks

Task: to ingest Ralph's points

Obstacles: Faddy's interruptions, I never attended the theater in London and have no frame of reference for Ralph's arguments Expectation: Ralph will win at least one person over to his side

\section{Bit G}

Title: The Vote

Task: to hesitate and waver in my immediate support for Ralph

Obstacles: I'm unsure as to whether Christ would support the play; yet, I want to move forward and aide my friend Ralph 
Expectation: the play will move forward, but Ralph will consult me and allow me to censor anything unholy

\section{Bit H}

Title: The final word

Task: to recover from Ross's tirade

Obstacle: it was completely profane

Expectation: Phillip will debrief with me and seek my counsel

After this method of script analysis, I collated the verbs and formed a list of tasks.

I also selected a line of text that struck me as a summation of the Bit to serve as a tuning fork of sorts. For example, in Bit B, I chose, "My wife abhors anything of that nature," due to its mention of my wife, a defense of women given Ross's attack on the convict women, and its mention of "nature," which to me meant both that type of play and the alternately sinful and righteous nature of man. Additionally, the word "abhors" provided room for elongation and an extended use of the breath on the letter "h." It proved useful when transitioning from primal sounds into language as described at the end of the following paragraph.

I then began utilizing Michael Chekhov's technique of Psychological Gesture as a means of physicalizing my Bit verbs list. Developed at the Moscow Art Theatre and later on in Hollywood, Psychological Gesture was Chekhov's way of taking language, transferring it into large movement, and then internalizing that movement to deliver text with life underneath it. Kinesthetic applications always helped me memorize my lines and through-lines of action. Remembering the physical sensations turned text into muscle 
memory in a way seated script analysis never could. The largess and gravitas of the Reverend also seemed particularly fitting for this grotesque and carnivalesque way of working. I wanted to find a way to bring my sketches to life, like a cartoon character had jumped off the page. Taking the Reverend's position of referee and physicalizing his tactics therein seemed an opportunity to relish in the messiness of the scene. I consulted Chekhov's list of basic or archetypal gestures: expand; contract; push; pull; lift; embrace; penetrate; wring; tear; and smash (Master Classes DVD). Take the verb "to mediate," for example. It began in the hands as a pushing from side to side, as if walls were closing in around me. I thought of the gesture like a virus, beginning in one part of the corpus and expanding outward to connected body parts, like an infection. Then I'd incorporate some guttural and primal sound to accompany the gesture as it coalesced into three distinct parts: the beginning; the gesture at its apogee; and its fading away. Next, I'd take my "tuning fork" line and pair it with the gesture, leading to an almost always grotesque or carnivalesque series of movements.

In order to play the tactical verb in stylistic consistency with the text and my fellow cast members, I began the process of "telescoping the work in," as Dr. Kelly put it. I delivered the text in what might be termed a realistic yet simultaneously theatrical means of expression. Internally, I remembered the sensations that accompanied the gesture at its most extreme. I believe this led to line deliveries teeming with life and intention under the surface, but appearing appropriate for the size of the character and playing space. In the example of the verb, "to mediate," I could make minute movements 
towards each person as they spoke and felt an enhanced sense of listening and either agreeing or disagreeing with them.

I employed this methodology of preparation before every single rehearsal for both Reverend Johnson and John Wisehammer. I would cycle through the task-list of verbs in the grotesque style and the result scrambled the line between theatrical movement and contemporary dance. Again this greatly eased memorization, as the somatic experience of performing the Psychological Gestures made the language and intentions a corporeal partnership. The ultimate results of my work were mixed. Since the Reverend made only a cameo appearance in one scene, his character could occupy a more fixed space where he did not need to change. Wisehammer had an entire arc to portray, appearing and reappearing many times throughout the play from first page to last. My addiction to the prep provided a useful and firm container in which to play the more archetypal Reverend, but cut off possibilities for discovery for the more fluid and sensitive Wisehammer.

One aspect of Stanislavki's notebooks on preparing for Othello included descriptions of Iago's past. Dr. Kelly asked us to do something similar and present these "monologues" to the rest of the cast. That night, we all stayed ninety minutes over time out of a shared joy and enthusiasm for the work. We communed through the art form of improvisation, and I found the greatest heights of free play that night. My backstories for Wisehammer and then for Johnson were as follows:

The name is John. But most everyone here calls me by my surname: Wisehammer. I was born in March of 1760, not entirely sure of the exact date on account of my mother died when I was born. Never 
quite forgave me for that, my dad. We lived in the East End of London, amongst a small community of other Jews, poor as hell. I learned how to find little odd jobs with the coster-mongers and the Jews in Duke's place. They're the brokers for foreign fruit and veg like pineapples, melons, Brazil nuts, that sort of thing.

My father cleared the houses of the dead to sell the old clothes to the poor houses by the Thames. That's a pretty common job amongst the older Jewish men. One day he was clearing out some building, and he found a dictionary, Johnson's dictionary, it was as big as a bible. It went from A to L and I started with the A's. I just sat there studying every word and taught myself how to read with help from a couple of the educated Jews down at the Synagogue. The fact that I could read made me a bit more useful. I kept ledgers for some of the coster-mongers, fruit and veg brokers, and even tutored some of them myself.

One day I was minding my own business just outside the snuff shop of Rickett and Loads. Wasn't having nothing but a conversation with some fruit seller when these chaps come running out of the store. Snoozie shows up and Mr. Rickett starts accusing me. Says I knicked a bag of his snuff. Before I know it I'm appearing before a judge who doesn't have a particular affinity for the Hebrew race. Tells me I'm to spend 7 years in Newgate or can be transported with the first fleet. I chose the latter, scared of what would happen to me in Newgate. If you 
ask me, the majority of people rotting away in there can be reformed. But the King and his magistrates don't care about that. They just want to punish us. In Newgate, one just rots away. Polishing the King's Iron with your eyebrows, they call it. I'd rather work than rot away. No one improves in Newgate. It's just a hole where they can forget about us for awhile. Their purpose is not reform, but terror, sublimation, and profit. How are we supposed to earn a living when most of us can't read or have any means to survive?

My name is Reverend Richard Johnson, though those close to me call me Dick. I was born on January 22, 1738 and turned fifty on the day we landed in Botany Bay. Though I seem much older, unfortunately. Several bouts of gout and rheumatism will do that to you. My parents were John and Mary Johnson, and I was born in Welton, Yorkshire. I've worked so hard to get rid of my Yorkshire brogue, to sound like a real London man, a man of the world. I attended Magdalene College as a sizar, meaning that I was given assistance in exchange for working as a curate. You might say the Church chose me more than I chose it.

Eventually I moved to London to work as an assistant to Henry Foster, a lovely preacher who was something of a surrogate father to me. After working as a curate for several ministers, I was appointed to serve as chaplain of the prison colony at New South Wales. My wife Mary and 
I would be tasked with guiding the spiritual life and education of the convicts. I believe that with a relationship with our dear lord and savior Jesus Christ, along with a proper education of the Bible, these sometimes monstrous prisoners can be reformed. They can marry, start farms, and have families.

Unfortunately, Governor Arthur Phillip feels that no convict labour can be spared to build my church. Arthur would rather stage a play. I support my dear friend Second Lieutenant Ralph Clark in his endeavor because I do believe in education, but it must be the right sort of education. And I have a fondness for Ralph as he is one of the few officers who does not engage in the sordid convict cohabitation I see so often amongst the officers. The possession of "she-lags," as they call them, is an affront to God. I seek always a house whose bed has not been sullied by convict concubinage. But I never had the time nor the incredulity to turn to the theater as a source of inspiration during my time in London. Could the theater really provide the change to our society Ralph suggests? Really, how can we ever turn these convict's lives around without a church? How I wish the officers and convicts were not so apathetic to the Divine World! And this play, the talk in this play. Silvia says she would have the wedding before consummation, while Plume is for consummation before the wedding! As far as he is concerned she could just go and lose her maidenhood her own way! 
This night showed me a new and different way to utilize preparation in the rehearsal hall. The differences in my choice of language for this exercise informed the physicality of each character. The more colloquial and self-deprecating Wisehammer kept his head down and drew into a fetal curve of passivity. The Reverend with his stuffy formality pulled up into extension keeping his chin and chest thrust in the air.

After delivering the speeches, I let them go completely and gave in to questions from the cast, focusing entirely on the present moment. I sat in the "hot seat" with my castmates interrogating me, testing the limits of my imagination and preparation. Though I went into the evening with a competitive attitude, my joy and surprise in the face of the ensemble's ingenuity made such concerns fade away. The particulars that did not matter, so far as the storytelling of "The Authorities Discuss the Merits of the Theatre" was concerned, fell by the wayside. By expanding my awareness to those around me, my need to entertain and show my homework melted away. I felt a real sense of companionship and camaraderie growing amongst the cast that night. This increasing sense of ensemble directly reflected the union amongst the convicts in Wertenbaker's play.

\section{The Rehearsal Hall}

As I carried my preparation into staging and working rehearsals, I perhaps remained too attached to the fragmentary nature of Bits. Stanislavski cautioned the actor, "Dividing a play and a role into small Bits is only permissible as an interim measure. The play and the role cannot be left in such a fragmentary form for very long" (140). Because the Reverend only occupied one scene, I was able to focus more on the notion of Supertask, the verb that described the overarching objective of the character for the entire 
play. In an effort to more clearly define Supertask, Stanislavski noted that, "Everything that happens in a play, all its individual Tasks, major or minor, all the actor's creative ideas and actions, which are analogous to the role, strive to fluff the play's Supertask" (307). As discussed earlier in the chapter, I conceived of Wisehammer as wanting to surpass Ralph Clark, losing sight of the desire for companionship so clearly expressed in the opening monologue when Wisehammer begs for some unseen woman to, “Take me inside you, whoever you are" (Wertenbaker 7). As a result, my fragmented Bits and Tasks were set askew and no coherent through-action could take shape. Once I recalibrated this to focus on Mary, my broken-down script came back together again, but never with the same surety and holistic quality of that magical callback.

As I looked back on my Task or Tactic descriptions, I noticed that the verbs engendered a lifting quality. Verbs like "assist, drum up, impress, support, protect" created gestures that came underneath Mary and raised her up, rather than drawing her towards me. Tellingly, my primary Task for the first monologue was, "To beg for companionship." Somewhere in the fragmentary nature of my smaller Bits and Tasks I lost the thread of the Supertask the director had given me point-blank at our first meeting: the audience had to believe Wisehammer was a credible rival for Mary's love. Because I found a through-action more akin to Quasimodo's relationship with Esmerelda, I had no hope of executing the director's original vision.

Stanislavski described three types of actors in whom either feeling, will, or mind dominated. These ran directly parallel to Chekhov's notions of imaginary centers that I mentioned in the previous chapter. Stanislavski wrote, "Actors of the third type - in 
whom the mind dominates feeling and will... unwittingly give the role an overly intellectual, cerebral emphasis" (282). As Wisehammer, my entire gait changed to where I led with the head and hunched my shoulders in a seeming desire to express his lowerclass status. Now I know that my habit lies in leading with the head in all matters, literally and figuratively. What was always supposed to be a more feeling character, the imaginary center in the chest, had become a thinking character centered in the mind. This overly intellectual and cerebral emphasis made the Reverend a satirical hoot, but muddled my interpretation of Wisehammer. Both characters became solo acts, fine for Johnson, but ill-fitting for Wisehammer, a team player who needed to fit in with the whole orchestra rather than trying to stand out all the time, out of tune and not in tempo.

Either I over prepared before rehearsals, simply engaged in the wrong type of preparation, or did both those things. At one point, about halfway through the process, I wrote, "In order to achieve the kind of results I'm looking for, a great deal of warming up and mediation will be necessary" (97). Immediately following that note I even questioned my overly cerebral approach to the written Thesis: "Is there a way my thesis could be less scholarly and structured more like a memoir or even fiction?" (97). I felt a struggle between my dual identities as scholar and artist, thinking of them as somewhat mutually exclusive and leaning towards the former because overly-intellectualized creativity, rather than a fearless and open sense of play, proved a more comfortable place.

Additionally, in an effort to prove my prowess and technique, I embodied the gestures engendered by my Task verbs to grotesque extremes too far into the rehearsal process, rather than telescoping those gestures and exercising restraint. Chekhov always 
intended that, "This gesture is never shown to the public. It must become an inner gesture, an archetypal image" (Petit 69). I wanted to control and telegraph the performance so I would know exactly how it was coming across. I believed in the folly that if I could not produce a truthful performance, at least I would produce a correct one. I wrote after one rehearsal of terrible frustration at the progress of the work:

When things work it's when I become less self-conscious, less aware that I'm acting. The awareness of hitting my marks isn't the problem, it's the constant questioning of how my performance is being perceived. I think about how my performance is coming across, which is ego-based fear. I need to focus on developing facility of my instrument and freeing it. I am coming up with choices rather than relying on response from observing the behavior of my scene partners. I'm making choices ahead of time and it's all becoming too studied. Allow yourself to listen more. (101)

A few days later, the director confirmed my suspicions by cautioning me that Wisehammer was becoming too studied and affected. We were playing the scene where Wisehammer asks Mary to marry him. The director reminded me that this was a sincere marriage proposal, and that simple note made the scene come to life. The overly technical approach to my gestures melted away as I stared into Mary's eyes and did not think about what I was doing, only asking her to marry me. I pondered, "Could it really be so simple? Could all the research and preparation really just be for the subconscious?" (103).

I found myself vacillating between a simple approach that focused on warming up the body and voice thoroughly versus a belief that coming back to my Bits, Tasks, and 
Psychological Gestures held the key. Notes like, "I just need to go further with the psycho-physical techniques" were immediately followed by, “The preparatory work is done alone, but what works so well for me is having a partner to listen and respond to" (105). In retrospect, I was having a crisis of faith where the techniques I had so faithfully employed in every role since late high school were failing me. I agonized over frustrating self doubt with questions like, "Why do I feel like my work is not enough? Why do I feel I must pull in 'high theory'?” (109). I kept spiraling downward. Each time a particular technique or combination of techniques failed me I grasped them harder and harder. If insanity is doing the same thing over again but expecting different results, I was one insane actor. "I need to effing relax!"' (111), I wrote after a particularly difficult rehearsal.

\section{Working In The Playhouse}

As we moved from rehearsal hall to The Belknap Playhouse, I doubled down on my interpretations of the characters. I noticed how, "It is very different working in the space. It feels massive. How can I increase the size of my performances without sacrificing truth and honesty?" (117). Dr. Kelly told me I was “calibrating” my performance and that what I was doing would read to an audience. "I feel like I'm overacting," I posited, "but really the work does require a certain size to it" (129). Convinced that my choices were cemented, and loathe to step too far outside the container I had established, I began to focus on what other people were doing wrong.

"This scene is a mess in terms of people picking up their cues," I wrote at one point 
(123). In Chapter Four I look at how these sentiments might be redirected positively in the future.

With the dialect coach's permission, I began writing down the mispronunciations of castmates and gave them notes. I was only supposed to help those using the same dialects as my characters, but of course I went beyond my purview, addicted to this small means of control to direct the production in some way. It engendered a self-satisfying feeling of superiority to my castmates as well. I asked Dr. Kelly if I could stage the curtain call, and he generously acquiesced. I was surrounded by collaborators and team players, yet I was all I thought about. I gained a confidence that perhaps gave way to cocksureness and began to see myself as too good to move set pieces. I lamented and wallowed in self-pity exclaiming, "What an effing nightmare. All these technical elements. I can't even act because I'm so focused on them” (137).

\section{There is no "I" in Team}

When the show opened, something released. Often the director stops giving notes at that point. With the actors prepared, the characters built, and the roles as fully created as they might come to be, I let go of the need to return to my score of actions. But as soon as the third performance, an unsettling and troublesome feeling reappeared. I wrote in my journal, "I believe this endeavor was a failure. I continue to struggle with all of the things I cannot control. Other people especially" (143). I wanted to melt and combine with the ensemble into one cohesive organism. Unfortunately, I remained a perfectionist obsessed with others and my own shortcomings. 
Particularly irksome were more muted audience reactions. I assumed that if the audience was not laughing or producing other sounds of testimony and delight that I was failing. At the fifth performance I wrote, "Tonight was by far our least responsive audience. How do you make adjustments when such things happen?" (145). The sixth performance provided the reactions I craved: "Wow! What a great audience tonight. I was absolutely blown away by their energy" (145). However, I do wonder if I mistook audible noises for feeling. Did I really feel worse about the fifth performance versus the sixth performance because of the audience, or was it because of my thorough warm up before the latter? By focusing on the health of my larynx instead of reviewing my written score and gestures again, I wrote, "My voice was in really bad shape when I came in. I was so happy with how I thoroughly warmed up and managed to rally with that warm up" (145). A focus on my body and voice took away the need to overthink the ensuing performance. What permeated all my journal entries after performances was the vexing question, "Do I need to feel what the character feels?... The question I keep asking myself is do I need to feel the devastation when Mary rejects me?" (147). A quote from Michael Chekhov appeared over a dozen times throughout the journal: "You can't always produce an emotion but you can always make a gesture" (147). I continued to rely on self-reliance, self-discipline, and self-confidence to bolster my ego throughout the run. But my entry after our closing night read, "The world amongst the ensemble is what matters the most. The world of the play is more about what the cast creates than the research" (147). Had I let go of the preparation and research and let it feed my subconscious without subsuming my conscious mind, had I accepted my inability to 
control others and technical elements, had I embraced the potential for a collectivist spirit that large-cast plays can offer in spades, perhaps choices could have come more from listening and responding than my own intellect. 


\section{CHAPTER THREE:}

\section{A SEARCHING AND FEARLESS INVENTORY}

This chapter provides an underview of the techniques employed in the creation of the roles and their alternate effective and hampering qualities, as measured by faculty feedback and honest introspection. I attempt to transform my own subjective recollections into more objective measurements. I particularly studied and fused two methodologies throughout the rehearsal process: Konstantin Stanislavski's notion of "Bits and Tasks"; and Michael Chekhov's “Archetypal or Psychological Gestures.” I reasoned that they share a mathematical quality of prescriptive formulas that if followed might lead to truthful performance. I find out in the course of this retrospective that, upon critical self-reflection, the "mathematics" of role creation was about as far as I ever got with my performances. Some ingredient of presence and vulnerability proved lacking when I finally took the stage. I never made room for the unquantifiable and ineffable qualities unique to each actor's proprietary talent and experience that could inform and respond to their fellow cast members.

This chapter has three primary arguments. First, technique cannot be learned solely from a textbook, but requires a "sensitive teacher-artist" or director to guide the pupil through the work based on their demonstrable success and belief in said technique. Second, one cannot merely study one aspect of a technique and expect the same results as if they had studied it in its entirety. I come to suggest that spontaneity borne out of 
individuality and response to the ensemble must always play a central role in the actor's work. Faith that myself and my teammates are enough to tell the story emerges as the crucial and missing ingredient in my journey through Our Country's Good.

\section{An Industrious Approach}

I am supremely proud of the process I employed before every rehearsal of splitting the scene into beats, bits, or units; identifying an objective, task, or tactic; and turning that into a Psychological Gesture. This particular means of synthesizing Stanislavski and Chekhov was a case study in my unique contribution to and innovation upon some of the foremost acting techniques of the twentieth century. Studying my methods could serve beginning actors well if they possess anxiety about what their preparation should look like beyond memorization and study of the requisite dialects. I codified a step-by-step process to ease performance anxiety and even aide in memorization by attaching text to specific movements. However, my attachment and eventual addiction to my methodologies sometimes cut me off from the present moment and resulted in an inability to respond and stay open to spontaneity based on reception of the partner. Here as well, my travelogue serves the intermediate or advanced actor as a cautionary tale of avoiding the trap of overly intellectualizing their work.

While the combination of Stanislavski's system and Chekhov's techniques proved immensely useful in the creation of the Reverend, somehow the vulnerability and honesty of Wisehammer was subsumed by similar caricature. The archetype and gesture work unique to Chekhov over-powered the verisimilitude Stanislavski sought. This larger-thanlife theatricality worked for a character as archetypal and stock in nature as the Reverend. 
Wisehammer demanded a simpler approach based more in the notion of ensemble, of listening and responding. I only realized this weeks after closing night, when reviewing faculty comments and watching footage from the final dress rehearsal. I felt like Trigorin in Anton Chekhov's Seagull when he declares that when he sees his work published he realizes all that's wrong with it (22). I saw my characterization of Wisehammer as more fraternal than romantic in his relationship to Mary.

In the case of both master teachers, I relied on their textbooks to guide me in my process, rather than the concrete experiences I'd had in the past when studying under teachers who had demonstrable success employing these techniques. Charles Marowitz discussed the problem of relying on textbooks in his biography of Michael Chekhov: "An acting technique, like any learned skill, depends not on the textbook but on the vouchsafed experience of the teacher applying it... Without qualified instruction by sensitive artists-teachers who have themselves experienced what they are trying to install in others, it can simply dwindle into cosmic psychobabble" (251). Turning acting theories into praxis in a practical classroom setting, under the tutelage of a credentialed teacher provided more weight to my explorations. With other students or castmates to play off of, this method of learning proved less cerebral and more full body. I could see the results in others and continue to incorporate the concepts of listening and response to stimulus. By working solo out of Chekhov's To The Actor, preparation became an act of intellectualization more than creation.

As a member of the Michael Chekhov association himself, I considered Dr. Kelly to be one of these "sensitive artist-teachers" Marowitz spoke of. He knew that I had 
immersed myself in the writings of and about Chekhov. He agreed to coach me privately on more than one occasion, and utilized Chekhovian ideas, such as Atmosphere. Since I trusted his direction, I went back to the textbook to see what Chekhov wrote about atmosphere as a compliment to and reinforcement of Kelly's guidance. However, instead of continuing to explore that aspect of the technique with more depth, I returned to the sections I found most interesting: archetype and Psychological Gesture.

By only engaging with a couple of facets of the Stanislavski System and Chekhov Technique, my explorations never penetrated a certain level of superficiality. In Lendley C. Black's biography of Chekhov, he cautioned the reader that an over-reliance on one aspect of a technique, such as Psychological Gesture, could shortchange and betray the effectiveness of the actor: "Regardless of the uniqueness, and what I perceive as the brilliance of the psychological gesture, it is in essence only one part of the actor's technique in Chekhov's complex acting system" (71). Perhaps the Chekhov Technique required a semester of study to engage with all the tools in his broad toolkit or application of each one to the role in some capacity. Marowitz echoed this sentiment when he wrote, "There is more to Stanislavsky than 'units,' 'emotional memory,' 'actions,' and 'objectives,' and a great deal more to Chekhov than 'radiation,' 'atmosphere,' and 'psychological gestures.' These are the convenient handles of an acting theory... To fully come to grips with...Chekhov...involves a protracted exposure to disciplines that underpin a metaphysical view of what an actor does and how he achieves his most profound results" (249). While I had studied Chekhov since 2008, I never had this prolonged or protracted exposure to a metaphysical view of acting. In an academic 
setting, where the director is both executive and teacher, I could have more fully engaged with Dr. Kelly's view of what an actor does. I certainly had extended exposure to training under his tutelage both in the production and our Shakespeare course that term. After all, he was present in the room with me, while Chekhov was long dead. Perhaps if I had set up more private working sessions and probed with more questions when in rehearsal, my ultimate interpretation of Wisehammer might have lined up more closely with his original vision for that character, thus fulfilling, fortifying, and lending credibility to the dynamics of the love triangle between Ralph, Mary, and Wisehammer.

A few weeks after the show closed, in my Advisory Committee meeting, Dr. Kelly introduced the idea that my exploration of the Chekhov technique was a surface exploration and that my main problem lay in my lack of relaxation. I became attached to the perceived "brilliance" Black and Marowitz spoke of. Rather than engaging with the present moment and drawing on personal experience, my head was buried in textbooks. Rather than seeking out a new experience and finding my own way through the roles, I was trying to replicate what seemed to work for others in the past.

I wanted to turn art into mathematics and science, forgetting that even students of Calculus most often studied with teachers rather than in an auto didactical fashion. Marowitz encouraged the reader to study with teachers, not books; to stay rooted in the spiritual notion of the present experience, instead of codified methods that are fixed and static:

When Chekhov was teaching, he drew on insights that he personally experienced as an actor, and tried, by means of practical applications, to 
re-create sensations he had known first hand... In the case of actor training, the touchstone is the teacher's inherent skill in identifying and reproducing the gifts that make acting remarkable and mesmerizing. Without those inherent skills, teachers are reduced to rehashing the tenets of a methodology that can produce results only when its formal precepts are transcended. A true believer, they say, has "seen the face of God," and something of that vision is retained in his nature that instinctively persuades others. A person who has never had an epiphany or throbbed with the sensation of spirituality is only going through the motions. (251)

I learned through this literature and retrospective analysis of my own work that experiences like Chekhov's cannot be consciously manufactured. When I was aware of the work and the technique, I became subsumed by the work and the technique. When I let my private work go and opened myself up to autonomic response from human stimuli in the room, I felt a sense of presence. I had a teacher right in front of me whose work I had seen as an actor, who had built a successful career and directed other productions in which I marveled at the technical and emotional prowess of its actors. In my preparation for the role I assumed the role of both student and teacher, actor and director, rather than embracing the rehearsal hall as classroom and laboratory, with Dr. Kelly as my guide. It was as if the rehearsal hall were merely the place to demonstrate my prowess and technical mastery, having achieved requisite proficiency in private study at home. I sought the approval of my director-teacher, wondering what he and my castmates thought of my work. I had no such higher quest beyond entertaining the audience, and impressing 
my peers and faculty. I lost sight of the spiritual aims and higher planes of consciousness I experienced in past roles when not so concerned with "routine application" of technique —when acting as a team player and letting go of the need to win the title of MVP.

While I remained deeply invested in the teachings and writings of Stanislavski and Chekhov, in order to grow I needed to stay open to the stimuli from my fellow sensitive actors as opposed to focusing solely on the theories espoused in books. Acting is experiential first and theoretical second. The acting theories and literature that stand the test of time are borne out of the genuinely lived experience of the authors. One learns so much more from doing than from reading. Thus teaching acting is more of a Homeric oral tradition than a written one. The textbook must only reinforce the in-class experience; it must be the frosting rather than the cake batter. I tried to bake two cakes almost entirely out of frosting, and it actually worked for the more archetypal and less subtle of the two. But like a debater who clings to the same arguments even though he has lost many rounds, I refused to change my game plan.

While I never succeeded in exploring the entirety of Stanislavski's and Chekhov's complex methods, there was still something very scientific about my approach because I saw my application of the "Bits-Tasks-Gestures" experiment through to the end. I had a clear hypothesis: a hybridization of Stanislavski and Chekhov's suggestions would lead to an increase in vulnerability and believability. I tested the theory and got my results. For roles like the Reverend that demand theatricality that pushes beyond verisimilitude, it works; for subtler characters who undergo heartbreak, it does not. Such roles require a more delicate and gradual process where the actor accepts and surrenders to the notion 
that they are enough to tell this story if they only relax and concentrate on responding to the text and scene partners in the present moment. If I could do it over again I would have abandoned my experiment in the case of John Wisehammer, but of course that's only in hindsight. I did not know my system was not fool-proof until watching the recording and hearing the feedback of the faculty. In retrospect, I find this mathematical and scientific approach to art rather puzzling. To try and wholly codify the mystic and spiritual experience of acting into a step-by-step system, to try and suck any esotericism from it seems to contradict why humans were drawn to the arts in the first place.

I thought the techniques of Archetypal and Psychological Gestures could help me stop thinking and help me start feeling. But the exploration of these techniques were born out of textbooks, not the guidance of a teacher. Chekhov hoped his techniques would combat an overly theoretical approach to acting. He wrote, "The intellectual approach to the part is one in which we try to dig deeper by means of thinking, instead of by making gestures, of finding the archetype, or other means" (Lessons 114). Yet for me, his gesture work was still in fact a form of intellectualizing and building a fortress-like performance, unaffected by the sometimes subtle and mysterious differences of stimuli from night to night while at play. That work happened in a vacuum where I worked solo. Clinging to the gestures and archetypes created in private study represented a kind of over-thinking as I clung to that preparation when moving into rehearsals. I made decisions based entirely on my own perceptions and opinions of the text and what it lacked for characterization, rather than autonomic and kinesthetic response based on speaking the text aloud, my scene partners, and my director. 
As long as I placed all my faith in my finite self, I lost the potential for my performance to commune with an infinite creative spirit of a collective universal unconscious. While corny, esoteric, or intangible to intellect, I had to make room for such sentiments and did not. I was afraid to be messy. Even applying the dirt make-up each night irked me. I wanted a clean, repeatable performance that varied little from night to night instead of providing an acknowledgement that some aspects of my experience could not and should not have been so codified.

Archetype, Psychological Gesture, Bits, and Tasks are wonderful tools towards the end of creative freedom of expression. But tools are a means towards creation, not the end product itself. As long as I sought to make technique consciously and clearly show up in my performances, I lost the possibility for discovery. Through a worship of Carl Jung's idea of archetypes, I forgot that those archetypes derive from a collective unconscious, or ensemble in the case of a play. Lenard Petit, a master teacher of the Michael Chekhov technique, took a very different view of Chekhov when he said that:

The ideas about acting developed by Michael Chekhov rely very heavily on this idea of collective energies. We find, through exercise and practice, that we can expect specific responses to certain images. If a room full of actors is asked to create a large movement of the physical body that could express the archetype of the hero clearly and succinctly, we would see that virtually everyone in the room will move in the same direction. Heroes are everywhere in history, in all the great literature, 
from David slaying Goliath, to Luke Skywalker defeating the evil Empire. This image lives in us. (67)

So much collective energy eluded me as I stayed stuck in my own head rather than communing with the ensemble. For me, images and movements as wellsprings of inspiration possessed greater efficacy when created in concert with my collaborators, just like that evening where we shared our backstories and asked each other questions. Petit's take on the technique constantly comes back to the idea of ensemble and emphasizes the similarities rather than the differences in how groups of actors respond to the different facets of the technique. Nothing occurs in a vacuum in Petit's book. He constantly returns to the idea of the partner and ensemble.

What I see in Chekhov and all his disciples is a grappling with egotism. While in theory they all espouse, "being purified of all egotism" (Petit 15), their methods rely on oneself alone in a room with the play, instead of in concert with other individuals. They claim to place the collective unconscious at the forefront of the technique, but remain attached to the individual will of the actor, "Towards making very defined and delineated movements which are aesthetically pleasing to watch and to execute" (Petit 68). Chekhov said that, "If you don't have the archetype...[you] will become a very small, dry, insignificant figure" (Lessons 113). Nowadays, I no longer believe that discarding the idea of archetype will necessarily lead to a "small, dry, insignificant" performance the way that Chekhov and his acolytes seem to suggest in their authoritative and absolutist manner. 
My indulgence in Chekhov's offerings of archetypal gestures was a finite resource I came back to again; the well was dry and still I sought water. Akin to, "The eight 'basic effort actions' identified by choreographer and dance educationalist, Rudolf Laban" (Chamberlain 63), and codified by the video course Master Classes in the Michael Chekhov Technique, the Archetypal Gestures were: open (expand); close (contract); push; pull; lift; embrace; penetrate; smash; tear; and wring. They could be used in conjunction with archetypes, such as The Lover, The King, or The Villain, and are the basis for finding the Psychological Gesture that can encompass a wider variety of verbs. Therefore, archetype and Archetypal Gestures are separate and distinct ideas. The moment I decided on a task or objective for a particular beat and determined its corresponding Archetypal and/or Psychological Gesture, I discounted the ability to throw those choices away. I over-prepared and was overly slavish to my experiment and this resulted in a surface exploration that simultaneously failed to provide either a deep exploration of the Chekhov technique or an effective performance as John Wisehammer in Our Country's Good. I needed to discover how to allow choices to come to me in the rehearsal room, but I pre-planned and made those decisions in advance and alone instead. In an effort to combat an image of laziness or incertitude, I could not allow myself to doubt the efficacy of my technique. I ignored Chekhov's own advice. While speaking directly to a group of actors in New York City he said, “"Every role requires its own technique,' suggesting that certain elements of the performance are already understood by the actor so they need no attention"' (Petit 5). I could not trust in my own experience, my director, nor my castmates, so I placed my trust in the writings of dead men. I placed 
Stanislavski and Chekhov in positions of Godliness, rather than recognizing that they were human beings searching for truth in art just like me. At the beginning of the Master Classes DVD, the teachers engage in a conversation where they say things like, "Don't trust in your talent, trust in your technique," and "If you can't give an inspired performance, give a correct one.” Now I am experiencing a crisis of faith in which I don't know whether placing my trust in "technique" and "correctness" will support my growth as an artist.

\section{Pedagogical Reconsiderations (A Side Note)}

While working on Our Country's Good throughout the Fall semester, I carried out my many other duties as Graduate Teaching Assistant and graduate student. As I revised my syllabus for a 300-level Acting course, I re-read the required textbook, Robert Cohen's Acting One, and considered adding to the mandatory course texts, A Practical Handbook for the Actor, written by six students of David Mamet and William H. Macy. Many of my students were first-time actors, and going back to basics influenced my preparation for the thesis role.

After a lengthy chapter on how to analyze a scene, I understood that Practical Aesthetics reduced a beat down to three essential components: what the character is literally doing; the essential action underneath that doing; and the "as if" (an example from the actor's own life that draws a comparison to the given circumstances in the beat). However, immediately following this offshoot of Stanislavksi's "Bits and Tasks," the authors discuss how "The Truth of the Moment" trumps all this preparatory work: 
An actor can very easily set in his mind exactly how a scene should be played. This is not the purpose of text analysis, nor is it desirable in terms of execution. The difficulty of executing an action lies in dealing with that which is actually happening in the other person. You can't execute your action in general; you must stay in tune with the responses you are receiving. This requires a great deal of bravery and will be due to the fact that you can never know exactly what is going to happen next. (40)

I saw this pre-planning to an extreme in my beginner students. When I would give an adjustment asking them to change the intention in a particular bit, they looked at me with abject terror. My novitiate students and I shared a common problem. Hooked on our homework, we could not let it go and live inside the scene work. We began to see text analysis as the end goal rather than a means to an end of living a character's private truth publicly and in responding to another human being. When teaching, I discussed listening, responding, and spontaneity at length, but I certainly did not prize it above the homework and a demonstration of understanding Cohen's GOTE (Goal, Other, Tactic, Expectation), itself just another even more mathematical offshoot of Stanislavski's system. I found myself wondering what had to come first: text analysis, or an ability to be spontaneous? Perhaps I shortchanged my students, thinking them incapable of artfulness and only able to grasp the craft of acting in a clinical and theoretical manner. I graded them based off of their GOTE sheet and written score, choosing not to grade them on the scene performances themselves, but rather the extent to which they understood my lessons as 
inspired by the textbook. Perhaps I cast myself as the "sensitive teacher-artist" instead of adopting the view that I myself am still a student, even while teaching.

Ironically, these two texts worked their way into my thesis role by increasing the craftiness of my approach. If acting is both art and craft, I figured it was better to do too much than too little with regard to picking up and honing in on the tools laid out in some best-selling acting books. I thought I had demonstrable evidence that these techniques had served me well in the past and they had, as far as "technique" and "correctness" were concerned. To become the "sensitive teacher-artist" Marowitz spoke of I had to make room for the possibility that a metaphysical and spiritual experience might consist of a connection to the non-habitual and unfamiliar spontaneity, rather than the printed word. 


\section{CHAPTER FOUR:}

\section{PRACTICING PRINCIPLES}

This chapter looks towards the future, strategizing and contemplating how I might achieve growth when it comes to diminishing the nagging egocentrism so apparent in my acting work thus far. Instructional texts on acting are employed; but, given the caveat from the previous chapter that acting technique cannot be sourced solely from acting textbooks, I also explore books from other disciplines such as: music; creative writing; and famous self-help books that aim to aide in transcending the chatter of our intellect. The Alexander Technique is also investigated, a practice I have studied for two years under the guidance of one of those "sensitive teacher-artists," Professor Rachel Carter. I draw a parallel and identify the unifying concepts between F.M. Alexander's "inhibition" and the Third Step laid out by Alcoholics Anonymous, nicknamed “The Big Book" in meetings. I conclude that a spirit of surrendering to a Higher Power and "nondoing" are essential to live a life predicated on healthy, sober, and creative recovery.

\section{The Third Step}

Step Three proved the linchpin in my grapplings with egocentrism as an actor. In Alcoholics Anonymous, the founders write that Step Three requires, "[Making] a decision to turn our will and our lives over to the care of God as we understood him" (59). After stumbling upon the Big Book of Alcoholics Anonymous on the recommendation of a friend, one passage stood out to me due to its direct references to my chosen field: 
Each person is like an actor who wants to run the whole show; is forever trying to arrange the lights, the ballet, the scenery and the rest of the players in his own way. If his arrangements would only stay put, if only people would do as he wished, the show would be great. Everybody, including himself, would be pleased. Life would be wonderful... What usually happens? The show doesn't come off very well. (60-61) Never had a quote so concisely summed up what had heretofore eluded me. From the audition process where I would stage scenes with other actors before bringing them in and showing them, to pre-planning my approaches to scenes for rehearsal, to my frustrations with castmates and technical elements upon moving into the space, I was trying to "run the whole show" from the stage. It seemed that the problems underlying addiction and alcoholism were identical to things I experienced in the rehearsal hall and performance. In the case of addiction, this anecdote was allegorical, but in acting I found I could apply it quite literally.

Additionally, the mention of God in Step Three led me to a belief in synchronicity, or an intelligent and caring Universe. This brought me comfort and faith to go on as an actor. Dr. Carl Jung once wrote a paper on such matters and I indeed found him to be the glue holding my research for this chapter together. Julia Cameron mentioned that, "Although Jung's paper on synchronicity was a cornerstone of his thought, even many Jungians prefer to believe it was a sort of side issue... Following his own inner leadings brought him to experience and describe a phenomenon that some of us prefer to ignore: the possibility of an intelligent and responsive universe, acting and 
reacting in our interests" (Cameron 65). I thought of the thousands of happenstances that had to occur for me to arrive at the present moment. Had I not bumped in to Dr. Kelly in the ballroom of the Times Square Crowne Plaza, 17 years after studying with him as a child, I never would have discovered U of L. Bill Wilson claimed that AA owed its origins to Dr. Jung and his patient Roland H., who went on the join the Oxford Group where he met Ebby T., who in turn carried the core message of the Twelve Steps to Bill W (Alcoholics Anonymous Comes of Age). Simultaneously, psychoanalysis and Jung's theories of archetypes of the collective unconscious gave rise to the techniques Stanislavski developed at the Moscow Art Theatre and subsequently Michael Chekhov. These supposed coincidences no longer strike me as coincidences. If I could only inhibit my habitual response of cynicism and wait for a new and unique response of faith, perhaps I could make God-consciousness habitual.

\section{A Pathway Forward}

After reading the faculty comments, I began to reflect on what went well and what I wished I had done differently. I began to strategize my approach in future acting endeavors. As I curated different texts, I started with The Actor's Secret by Betsey Polatin, a tome largely dedicated to the Alexander Technique. Unlike Chekhov and Stanislavski, for the past two years I studied the Alexander Technique and Polatin's book in concert with one of those "sensitive teacher-artists" mentioned in the previous chapter, my Voice Professor and dialect coach, Professor Rachel Carter. While I had studied Chekhov and Stanislavski in the past, I side-stepped an opportunity to really apply principles of Alexander with Wisehammer and Reverend Johnson. I used the technique as 
more of a spice than a protein, icing rather than cake batter. Professor Carter's classwork that semester consisted of very thorough text work with a final emphasis on throwing that work away and living in the moment. After the completion of the thesis role in the Fall, I took private lessons with her where we might spend a half hour just trying to sit and stand with ease. By asking me to slow down and approach movement, voice, and speech from a place of poise, tone, and "nondoing" and not a place of holding, tension, or collapse, selfawareness ceased to be synonymous with judgment and criticism. The directions I gave myself in the Alexander work consisted of thoughts like, "Free my neck," or "allow my pelvis to shift back." By giving direction without putting a harsh judgment on top of it, I found freedom to receive stimulus from my acting partners. Just like the performance where I focused on my warm-up instead of analysis, attention on body awareness proved a cunning antidote to self-conscious over-thinking.

The particular modalities of script analysis and Psychological Gesture that I developed wound up as a means to control and "make something happen" in the face of not feeling. Polatin cautioned against this trap in her book while describing a student who felt she was coming up short: "Instead of trying to feel the generosity that she did not feel, I asked her what it would be like to pay attention to what she did feel" (5). Rather than pursuing the sensations of the present moment, I remained fixated on some imagined end product or a goal of some emotional achievement. In my preparation and rehearsal for Wisehammer and the Reverend, I kept pursuing technique to make up for perceived shortcomings. Polatin encouraged me to focus on and trust in my assets, rather than trying to cure my defects. 
This anecdote bore close resemblance to Third Step and Seventh Step literature found in Alcoholics Anonymous. By focusing on the feelings present, rather than pushing for feelings that were absent, I thought of this ""nondoing"” as a form of surrender. In Step Seven, the founders wrote, "[We] humbly asked [God] to remove our shortcomings" (Alcoholics Anonymous 59). The author's perception that God controls the time table within which we recover echoed my own need to practice humility in objectively recognizing the talent and experience I brought to the table while allowing the director, Dr. Kelly, and the ultimate Director, a Higher Power, to help fill in the holes.

The idea of unblocking and undoing brought me back to The Artist's Way, the 12week workbook I made great use of the summer before the production. Cameron's text asked me to look at learned patterns of behavior before I tried to create a role again. Cameron suggested that, "By tossing out the old and unworkable, we make way for the new and suitable" (83). Instead of adding details like clenched fists and a hunched-gait for Wisehammer, instead of indulging in my "old" habits for low-status characters, I needed to make room for "new and suitable" choices to come to me through unblocking. I saw immense synchronicity between practitioners of acting pedagogy like Polatin, creative writers like Cameron, and the founders of Alcoholics Anonymous. What F.M. Alexander termed "inhibition" (Use of the Self v), Cameron called “surrender" (Artist's Way 82) and AA called "turning it over" (Alcoholics Anonymous 59). Rather than making acting choices, I wanted to re-frame that habitual thinking into allowing choices to come to me. All these teachers called for open-mindedness, willingness, and the chance for an expanded notion of self. When Polatin said, "The work 
we do here is not a question of eliminating habits, but a question of reintroducing parts of the self that have, for one reason or another, become exiled" (30). For example, from the ages of 15 to 25 , I did not cry. I was anesthetized by the perception that masculinity and crying were mutually exclusive. I also over-indulged in various forms of material pleasure as a means of self-medication. I thought of those lost parts of self as more Godly parts of self. She went on, "The idea is not to counteract, but to release" (34). Cameron invoked a Sanskrit word to describe this same idea of "release": "We learn what we want...But not without a kriya...meaning a spiritual emergency or surrender...In twelvestep groups, kriyas are often called surrenders. People are told just let go" (81-82). At the end of her book, Cameron offers a suggested reading list (233-37). Unsurprisingly, she recommends several texts published by Alcoholics Anonymous World Services.

\section{A "Nondoing” Doing}

I really thought my acting technique would lead me to spontaneous performances, but it turned out that perceived spontaneity can really be habitual spontaneity. As Polatin points out, "Many actors think that they are being spontaneous when what they are in fact doing is behaving habitually" (110). She insists that we instead take a surrendering, or "nondoing" approach: "Inhibition, or 'nondoing', is the Actor's Secret. To respond with nonhabitual behavior, doing less can allow a totally different interpretation to surface" (108). Had I focused on nondoing perhaps a less studied Wisehammer could have emerged more in line with the director's vision. By arriving at a performance of

Wisehammer that garnered belly laughs but failed to emerge as an earnest romantic rival, I felt incredibly creative and expressive, but that creativity and expression wound up 
running counter to the director's interpretation of the text. In the introduction to his book The Intent To Live, Larry Moss spoke of a student who, while playing Treplyev in Chekhov's Seagull, began to violently push Nina around the room in their final scene (11). He wanted to banish the notion of Treplyev as victim, yet these impulses negated the text. If Treplyev attacked her, Nina would have to acknowledge it; but she seemed blatantly oblivious to his feelings. Moss said that, "His desire to be creative and express himself blinded him to the needs of the play" (11). In my case, this rather egocentric goal of self-satisfaction ran the show. In Our Country's Good, Wisehammer had to be a credible romantic rival for Mary's love, otherwise her choice of Ralph would be a forgone conclusion. What I thought of as natural or creative choices for Wisehammer were in fact habitual choices, particularly when it came to low status characters. The shuffling gait, the round shoulders, the lowered head, the comic goofiness - these were my go-to traits because directors had lauded me in the past for these choices and audiences laughed and applauded. I wanted to entertain the audience more than I wanted to tell them a story.

Alexander himself provided great advice when he wrote, "I must not concern myself primarily with 'doing', but with preventing myself from doing — preventing myself, that is, from giving consent to gaining an end by means of that habitual 'doing' which resulted in my repeating the wrong use of myself that I wished to change" (18). Rather than focusing on being or ""nondoing"," on listening and responding to the nuances of the language and the scene partner, I kept trying to direct the scene while simultaneously playing it. I knew all the beats and reactions required of me. Polatin 
called this type of self-direction as an engagement in "emotional appointments":

"Someone might decide that when their scene partner says, 'I do not love you anymore,' he or she has a plan that they will cry at that moment. With emotional appointments, you do not have to be open and vulnerable in the present moment. You do not really have to feel much of anything" (152). I scheduled these appointments in my study at home and prepared to execute what I thought each scene required of me from solo exploration. I knew Mary would reject my marriage proposal long before asking her. Every night I remembered to have that "emotional appointment" of dejection and thus became desensitized or even numb to it. While the audience understood that heartbreak and peripeteia, I don't know that they ever believed it since I never gave Wisehammer the chance to believe she might say yes. Alexander calls this focus on the future, seeing the journey as only a means to an end, "endgaining" (Polatin 99). Polatin insists that if we instead focus on the "nondoing" and "inhibiting," "What we end up with as a result...we call presence" (119).

My stubborn habit lay in returning to old methods of working as a means to avoid "presence" and numb out. Cameron continually reminded me that my faith in theory and technique over listening and giving up control were a sort of addiction. She said, "We ourselves are the substance we withdraw to, not from, as we pull our overextended and misplaced creative energy back into our own core" (6). This "substance" was thinking and the belief that I could think my way into a truthful performance. My "core" was my mind rather than my heart center, and so Wisehammer could not find the right spot to 
bloom within my kinesthetic sphere. I pushed out a potentially grander and more moving characterization with the very techniques I hoped would achieve such an end.

In Harold Guskin's How To Stop Acting, he recounts a realization that Stanislavski could only take him so far. This closely mirrors my own understanding of acting as an art form. Stanislavski's templates for thorough script analysis from beat to beat, with the objectives carefully thought out, eventually came up short. Guskin writes that:

At first my work impressed directors and audiences... But after a while, I found that when I was on stage, both in rehearsal and in performance, I wasn't as free as I knew I needed to be... I was so diligently trying to 'play my objective' that I was not free to do anything else on stage. I was not in a genuine state of exploration, so my acting was not surprising, to me or to the audience. I was too neat, too logical. My characters lacked the amazing variety of life. (xvi)

This "neat" and "logical" approach served me well as far as Reverend Johnson was concerned. I did not need to delve deeper than a stock character and comic approach to convey the satirical nature of, "The Authorities Discuss the Merits of the Theatre." But Wisehammer represented one of those rich, complex, and deep characters that would require an expanded use of self, an openness and vulnerability that could only grow if old and unworkable habits were left aside. Guskin insisted that, "The actor's work is not to create a character but to be continually, personally responsive to the text, wherever his impulse takes him, from first read-through to final performance" (xx). As I pondered in 
my journal, perhaps this simple but difficult approach of openness and experiential presence held the key to truthful performance.

Textbooks and theory provided me with a useful foundation that I stand by, but the true muse of creativity comes not from books, but inhibition and surrender. As the violinist Stephen Nachmanovitch put it in his book Free Play, "When we see technique or skill as a 'something' to be attained, we again fall into the dichotomy between 'practice' and 'perfect,' which leads us into any number of vicious circles... Technique can get too solid — we can become so used to knowing how it should be done that we become distanced from the freshness of today's situation" (67). This idea of perfectionism proved toxic to my creative life. Perfectionism represented fear-based blockages to creativity, an inability to give into the unknown. Polatin reinforced this notion as well by emphasizing a "balance" between "acting work" and "inner work": "It is important to find a balance between your acting work (playing objectives, minding blocking) and your inner work (direction, inhibition, and sensory tracking). If you act without your inner work, you rob yourself of subtle connections and choice. If you do your inner work and forget these acting guidelines, you can end up feeling purposeless" (184). I experienced an imbalance that weighed heavily in the direction of "acting work" as opposed to "inner work." I felt tremendous purpose throughout the process but missed out on those "subtle connections."

As I turned my attention towards literature well outside the bounds of aiding in creativity, The Power of Now caught my attention with its brazenly titled first chapter: "You Are Not Your Mind" (11). Eckhart Tolle, in this bestselling book on cultivating spirituality as a means towards contentment, described each of us as two distinct beings: 
the "I" and the "self." He writes, "I cannot live with myself any longer.' This was the thought that kept repeating itself in my mind. Then suddenly I became aware of what a peculiar thought it was. 'Am I one or two? If I cannot live with myself, there must be two of me: the 'I' and the 'self' that 'I' cannot live with.' 'Maybe,' I thought, 'only one of them is real"" (4). The "I" he spoke of reminded me of my own embryonic conception of God, a Higher Power, a Universal Energy present in every man, woman, and child. I became convinced that if I were to ever overcome my egocentrism while acting, some kind of concept of spirituality needed to take hold - one that positioned the Universe as caring and responsive - aiding us so that we might help other human beings along on their journeys.

All of my fear surrounding my reputation, as if the play were a competition to be won, served only to block off my potential to act as a prism of creativity through which my Creator might operate. I discounted that emotionally connected experiences could manifest of their own accord without needing to do anything besides staying open and unblocked. As an actor relying on techniques, I ceased to be a human-being and instead became a human-doing.

Bill Wilson, the co-founder of AA, spoke of the potential for spiritual illuminations borne out of open-mindedness and a willingness to believe. In AA Comes of Age, one of his speeches was reprinted as follows: "It was Ebby, I think, who brought me a copy of William James' Varieties of Religious Experience... Spiritual experiences, James thought, could have objective reality; almost like gifts from the blue, they could transform people. Some were sudden brilliant illuminations; others came on very 
gradually. Some flowed out of religious channels; others did not" (64). I found a direct parallel between Polatin's "acting work" and "inner work" and this merger of "spiritual experience" and "objective reality." Even now, my inclusion of all this quote-based evidence runs counter to my belief that my own words might be enough to transform others, that my Thesis could be a "gift from the blue" to some future student who stumbles upon it when they utilize the right combination of Boolean operators.

\section{Conclusion}

At some point I had to forgive myself for the creative failure of Our Country's Good and accept that what had happened did not need to be labeled as good or bad. The way I played the role was the way I needed to play the role at that point in my journey. And after all, how could I write a reflective paper of this depth if the performance had been perfect? Through the imperfections of my performance I have learned so much about what steps I might take to pursue this professionally without going mad.

In an academic environment, we are subjected to intense scrutiny and criticism. It is how we are meant to grow. There is a reason why the program lasts for three years, and not a lifetime. To have your skill set as an artist put under such an intense microscope at all times is difficult and sometimes debilitating. I had to trust that my talent and experience was still valid, even in the face of highly critical and hard-to-hear feedback from my professors. I chose a path of humility, to see myself as a beginner again, perhaps even a "bad artist," who pushed through the fear of trying things in a new and nonhabitual way. I turned back to what went well, my dedication to honing and excavating the craft of acting through a spiritual lens. Mark V. Olsen's Golden Buddha Changing 
Masks provided much comfort. He reminded me that, "You...have...been exposed to one or more of the lines of esoteric spiritual teachings that lead toward self-realization, enlightenment, or religious devotion. In short, you are a seeker” (5).

Reading the criticism of my performance was a sort of nadir, a low point of humiliation where I felt inadequate, foolish, and unworthy to call myself an artist. However, all the texts mentioned in this chapter spoke of such a valley as being essential to artistic growth. Tolle spoke of experiencing such a "dark night of the soul":

I understood that the intense pressure of suffering that night must have forced my consciousness to withdraw from its identification with the unhappy and deeply fearful self, which is ultimately a fiction of the mind. This withdrawal must have been so complete that this false, suffering self immediately collapsed, just as if a plug had been pulled out of an inflatable toy. What was left then was my true nature as the everpresent I am: consciousness in its pure state prior to identification with form. (5)

While I have had flashes of this sense of peace and serenity, I know that continuing to search and seek it out through the "nondoing" that meditation affords will be highly necessary. Stephen Nachmanovitch encouraged exploring this "emptiness" or vacuum that opens up to invite pure consciousness: "Discipline is crucial, but we do not attain it by stiffening up. We attain it by sitting still and penetrating the emptiness within, making of that emptiness a friend rather than an adversary or bogeyman" (141). This "nondoing" 
is a technique not only for acting but for living a life of contentment and serenity. It turns out it is hard work and requires tremendous patience to "nondo."

I started by looking at some fundamental behaviors that could set my actor-self up for success: eating less processed sugars and more vegetables; exercising a few times a week; and sleeping 7-8 hours each night. Cameron reminded me that, "Each of us is a unique, creative individual. But we often blur that uniqueness with sugar, alcohol, drugs, overwork, underplay, bad relations, toxic sex, underexercise, over-TV, undersleep - many and varied forms of junk food for the soul" (85). Polatin also closed her book with some suggestions of setting oneself up for success with the Alexander work. She encouraged the reader to eat well, exercise, and get enough rest. As I wrote much of this, I ate ice cream, watched television, and frequently wrote all night, eschewing sleep.

Again, as in Alexander, artistic growth was to be more about undoing blockages and rediscovering parts of myself to create an expanded self, parts lost to an overly technical and intellectual approach accompanied by comforting and numbing material addictions like sugar and caffeine; parts lost to the onset of adolescence banishing my childhood sense of free-play. Nachmanovitch described all creative works as already inside of us: "How does one learn improvisation? The only answer is to ask another question: What is stopping us?... What we have to express is already with us, is us, so the work of creativity is not a matter of making the material come, but of unblocking the obstacles to its natural flow" (10). Like the other writers cited in this chapter, to achieve truthful performance I need only get out of my own way-something that is both extraordinarily simple and terribly difficult. This quote could have easily come from 
Alexander or Polatin with slightly different wording. He identified with this "I versus self" concept that Tolle, Alcoholics Anonymous, and Julia Cameron all tapped into. He wrote, “My experience of playing....is that 'I' am not 'doing something'; it's more like following, or taking dictation" (4). My technique, intellect, and course of study were excellent jumping off points, but as I wrapped up the thesis I discovered that a constant renewal of surrender, inhibition, and giving up control would be essential to my growth as an artist. 


\section{REFERENCES}

Alcoholics Anonymous: The Story of How Many Thousands of Men and Women Have Recovered from Alcoholism (Fourth Edition). Alcoholics Anonymous World Services, 2001.

Alexander, Frederick Matthias. The Use of the Self. Metheun \& Co, 1941.

Black, Lendley C. Mikhail Chekhov as Actor, Director, and Teacher. U of Michigan, 1987.

Cameron, Julia. The Artist's Way: A Spiritual Path to Higher Creativity. Penguin Random House, 2016.

Chamberlain, Franc. Michael Chekhov: Routledge Performance Practitioners. Routledge, 2004.

Chekhov, Anton. The Seagull. Translated by Ross Shenker \& Yoram Shenker. SelfPublished, 2013.

Chekhov, Michael. Lessons For The Professional Actor. Transcribed and Arranged by Deidre Hurst du Prey. Performing Arts Journal, 1985. , __. On The Technique of Acting. Harper, 1991.

— - The Path of the Actor, edited by Andrei Kirillov and Bella Merlin. Routledge, 2005.

Farquhar, George. The Recruiting Officer, edited by Michael Shugrue. U of Nebraska, 1965. 
Goldentul, Zhanna. Costume Design Sketches. U of Louisville, 2017.

Guskin, Harold. How To Stop Acting. Faber and Faber, 2003.

Hogarth, William. A Rake's Progress. Oil on Canvas, 1734. Sir John Soane's Museum.

Hughes, Robert. The Fatal Shore: The Epic of Australia's Founding. Random House, 1986.

The Incredible Journey of Mary Bryant. Created by Peter Berry, performance by Romola Garai, Film Rise, 2005.

Jung, C.G. The Portable Jung: Edited by Joseph Campbell. Penguin Books, 1976.

Keneally, Thomas. The Playmaker. Simon and Schuster, 1987.

Marowitz, Charles. The Other Chekhov: A Biography of Michael Chekhov, the Legendary Actor, Director \& Theorist. Applause Theatre \& Cinema, 2004.

Mayhew, Henry. London Labour And The London Poor, Volume II. Dover Publications, 1983.

Moss, Larry. The Intent to Live. Bantam, 2005.

Nachmanovitch, Stephen. Free Play: Improvisation in Life and Art. Penguin, 1990.

Olsen, Mark. The Golden Buddha Changing Masks: An Opening to Transformative Theatre. Gateways, 2006.

Petit, Lenard. The Michael Chekhov Handbook. Routledge, 2010.

Polatin, Betsey. The Actor's Secret. North Atlantic, 2013.

Pollock, Della. "The Performative I," Cultural Studies and Critical Methodologies, Volume 7 Number 3, 2007. U of North Carolina at Chapel Hill. 
"Psychological Gesture." 2006. Master Classes In The Michael Chekhov Technique, created by Joanna Merlin, Leonard Petit et. al., episode 7, Routledge, 2007, disc 2 .

Shenker, Ross J. Process Journal. U of Louisville, 2018.

Stanislavski, Konstantin. An Actor's Work, translated by Jean Benedetti, Routledge, 2010.

- $\longrightarrow$. An Actor's Work On A Role, translated by Jean Benedetti, Routledge, 2010.

Steiner, Rudolf. The Philosophy of Freedom. The Rudolf Steiner Press, 1964.

Tolle, Eckhart. The Power of Now. New World Library, 2004.

U of L Faculty, Committee Review Sheet. U of Louisville, 2017.

Wertenbaker, Timberlake. Our Country's Good. The Dramatic Publishing Company, 1988. 


\section{CURRICULUM VITA}

NAME: $\quad$ Ross Joel Shenker

ADDRESS: 4610 Waukesha Street

Madison, WI 53705

DOB: $\quad$ Madison, WI - March 16, 1989

EDUCATION

MFA in Performance

University of Louisville, Louisville, $K Y$

May 2018

Thesis Title: Gestures of Creative Recovery for the Egocentric Actor through Timberlake Wertenbaker's Our Country's Good

Thesis Committee: Dr. Janna Segal, Professor Rachel Carter, Professor Paul Griner

BA in Theater, Certificate in Jewish and Israel Studies

Wesleyan University, Middletown, CT

May 2011

ACADEMIC TEACHING EXPERIENCE

Department of Theatre Arts, University of Louisville

Acting Instructor January 2017-Present

- Instructor of record for three sections of Theatre Arts 324 (Acting For Non-Majors) over three semesters

- Planned and taught undergraduates in an intensive beginning course based upon Stanislavskian techniques in contemporary realistic styles of acting

- Used Blackboard and other online tools to enhance pedagogical technique

- Utilized theater games, improvisation, vocal and physical exercises, open scenes, and scripted scenes by playwrights such as Kenneth Lonergan, August Wilson, Annie Baker, Donald Margulies, and many others

- Completed Acting Pedagogy course prior to instruction

Department of Music, University of Louisville

Voice Instructor

January 2017-Present

- Completed Advance Vocal Pedagogy course under Dr. Katherine Donner

- Brought in private undergraduate voice students to demonstrate teaching technique for course 
Department of Theatre Arts, University of Louisville

Graduate Teaching Assistant

August 2015-May 2016

- Served as a Graduate Teaching Assistant for Professor Johnny Jones for Theatre Arts 207 (Enjoyment of Theater)

- Taught three separate sections of undergraduates for Friday recitations for each of two semesters

- Utilized Power Point and other electronic media to enhance pedagogical technique

- Recorded grades and assisted in creation of quizzes and exams

\section{WORKSHOPS}

Timber Lake Playhouse, Mount Carroll, IL

Acting Instructor

Summer '16 \& '17 Seasons

- Served as instructor for devised theater workshop for youth ages 12-18

- Served as instructor for musical theater workshop for youth ages 7-11

Private Studio

Musical Theater/Voice Coach

August 2014-Present

- Continually serving as voice coach and accompanist for students ranging in age from $14-26$

\section{DIRECTING EXPERIENCE}

Director

How To Start A Wildfire

School of Rock

Grease

Seagull Project

The Grasshopper

Clippies

Studio Theatre Company

Timber Lake Playhouse

Timber Lake Playhouse

Studio Theatre Company

Studio Theatre Company

The Judgment

Clear Plastic Theater Company

Wesleyan University Second Stage

Assistant Director

Vanya and Sonia and Masha and Spike

University of Louisville

Fiddler On The Roof

Children's Theater of Madison

Music Director/Accompanist

Hostage Song

Music Theatre of Madison

You're The Flop

Music Theatre of Madison

The Addicts

Theatre For The New City

ACTING EXPERIENCE

Our Country's Good Wisehammer/Johnson University of Louisville

Antigone

King Lear

Sentry

Fool 


$\begin{array}{lll}\text { Bloodline Rumba } & \text { Prado } & \\ \text { Polaroid Stories } & \mathrm{D} & \\ \text { Titanic, The Musical } & \text { Edgar } & \text { Timber Lake Playhouse } \\ \text { The Addicts } & \text { Host } & \text { Theater For The New City } \\ \text { But I'm A Cheerleader } & \text { Joel } & \text { Capitol City Theatre } \\ \text { Richard III } & \text { Hastings/Tyrrell } & \text { Wesleyan University CFA } \\ \text { Sweeney Todd } & \text { Sweeney } & \text { Wesleyan University Second } \\ \text { Stage } & & \end{array}$

\section{ADMINISTRATIVE EXPERIENCE}

Affirmative Entertainment

Talent Assistant

July 2012-December 2012

Managed client Facebook pages and websites, served as executive assistant to CEO, rolled calls, managed calendars and call lists, submitted clients for auditions, read scripts for Tuesday staff meetings, coordinated payments and billings between business manager, $\mathrm{CPA}$, and clients, performed various gopher tasks with vehicle

\section{Innovative Artists Agency}

Agent's Assistant August 2011-July 2012

Managed client websites and Breakdown Express pages, served as executive assistant to Agents in the Comedy Department, sold Personal Appearances to Universities and Comedy Clubs for clients, answered phones, rolled calls, maintained correspondence with partner talent managers and clients via e-mail

Warner Brothers Pictures

Script Reader

June 2011-August 2011

Read and wrote coverage on screenplays, teleplays, optioned properties, etc. Answered phones, rolled calls, maintained correspondence with other offices via e-mail

HONORS AND AWARDS

Howard Needler Prize For Excellence In Jewish And Israel Studies

Wesleyan University, May 2011

\section{SPECIAL SKILLS}

Sight reading for piano/accompanying for musical theater, music direction, conducting, Blackboard, Moodle, Power Point, Excel, Word, Pages, iMovie, Garage Band, arranging/ notation/composition, fluent in Spanish, understands Hebrew 